\title{
New deep water skates of the genus Notoraja Ishiyama, 1958 (Rajoidei, Arhynchobatidae) from the southwest Pacific
}

\author{
Bernard SÉRET \\ IRD /Muséum national d'Histoire naturelle, \\ Département Systématique et Évolution, \\ case postale 51, 57, rue Cuvier, F-75231 Paris cedex 05 (France) \\ seret@mnhn.fr \\ Peter R. LAST \\ Wealth from Oceans Flagship, CSIRO Marine \& Atmospheric Research, \\ GPO Box 1538, Hobart, Tasmania 7001(Australia) \\ peter.last@csiro.au
}

KEY WORDS

Arhynchobatidae, skates, southwest Pacific, New Caledonia, Vanuatu, Fiji Islands, Norfolk Ridge, new species.

MOTS CLÉS Arhynchobatidae, raies, Nouvelle Calédonie,

Vanuatu, îles Fiji,

ride de Norfolk, sud-ouest du Pacific, espèces nouvelles.
Séret B. \& Last P. R. 2012. - New deep water skates of the genus Notoraja Ishiyama, 1958 (Rajoidei, Arhynchobatidae) from the southwest Pacific. Zoosystema 34 (2): 319-341. http:// dx.doi.org/10.5252/z2012n2a9

\section{ABSTRACT}

Four new skates of the genus Notoraja Ishiyama, 1958 are described from the rarely accessed, deep waters off New Caledonia, Vanuatu and Fiji islands, and the Norfolk Ridge. Three of these (N. alisae n. sp., N. longiventralis n. sp. and $N$. fijiensis n. sp.) are "velcro skates" which are characterised by their velvety dorsal and ventral surfaces, covered with fine denticles. Although similar in shape, they differ by their colour pattern, dermal armature, development of the lateral tail folds, and size of the pelvic-fin anterior lobe and nasal curtain. The description of the fourth species, Notoraja inusitata n. sp., is based on a juvenile male exhibiting some unusual features resembling those of other skate genera.

\section{RÉSUMÉ}

Nouvelles espèces de raies de profondeur du genre Notoraja Ishiyama, 1958 (Rajoidei, Arhynchobatidae) du sud-ouest du Pacifique.

Quatre espèces nouvelles de raies du genre Notoraja Ishiyama, 1958 sont décrites des eaux profondes, rarement échantillonnées, de Nouvelle-Calédonie, du Vanuatu, des îles Fidji et de la ride de Norfolk. Trois de ces espèces (N. alisae n. sp., $N$. longiventralis n. sp. et $N$. fijiensis n. sp.) sont des raies «velcro» caractérisées par le toucher velouté de leurs faces dorsale et ventrale qui sont couvertes de fins denticules cutanés. Bien que semblables en apparence, ces raies diffèrent par leur colouration, leur armature dermique, leur repli cutané caudal plus ou moins développé, la longueur du lobe pelvien antérieur et celle de la valvule nasale. La description de la quatrième espèce, Notoraja inusitata n. sp., est basée seulement sur un jeune mâle qui présente des caractères inhabituels rencontrés dans d'autres genres de raies. 


\section{INTRODUCTION}

The arhynchobatid genus Notoraja Ishiyama, 1958, presently comprises seven species: $N$. azurea McEachran \& Last, 2008, from southern Australia; $N$. hirticauda Last \& McEachran, 2006, from western Australia; N. lira McEachran \& Last, 2008, from the southeastern Indian Ocean; $N$. ochroderma McEachran \& Last, 1994, from northeastern Australia; N. sapphira Séret \& Last, 2009, from the Norfolk Ridge; N. sticta McEachran \& Last, 2008, from the Great Australian Bight; and N. tobitukai (Hiyama, 1940) from Japan. All of these species have a smooth ventral disc, entirely devoid of denticles. Other nominal species, once placed in the genus Notoraja, were re-assigned by Last \& McEachran (2006) to their new genera Brochiraja (i.e. B. asperula (Garrick \& Paul, 1974) and B. spinifera (Garrick \& Paul, 1974) from New Zealand) and Insentiraja (i.e. I. laxipella (Yearsley \& Last, 1992) and I. subtilispinosa (Stehmann, 1989) from the western central Pacific) was assigned to Insentiraja by Compagno et al. (2005) and McEachran \& Last (2008).

Several specimens of a subgroup of Notoraja were collected during the following deep-sea exploratory cruises and fishery surveys: HALIPRO 1 (New Caledonia, 1994), MUSORSTOM 8 (Vanuatu, 1995), HALIPRO 2 (New Caledonia, 1996), MUSORSTOM 10 (Fiji, 1998), NORFANZ (Norfolk Ridge, 2003), and the SANTO expedition (Vanuatu, 2006) (cf. Grandperrin et al. 1995, 1997; Richer de Forges et al. 1996; Séret 1997; Williams et al. 2006; http:// www.santo2006.org/). The skates of this subgroup of Notoraja were subsequently called "velcro skates" by Andrew Stewart (Te Papa, New Zealand) in reference to their similarity to a fabric covered with tiny hooks; the dorsal and ventral surface of these skates are densely covered with fine denticles giving them the appearance and touch of this fabric. The ventral skin is devoid of dermal denticles in other Notoraja species. The other features of the velcro skates fit with those of the genus Notoraja as defined by Stehmann (1989) and McEachran \& Last (1994).

These skates, considered distinct from already named Notoraja species, and from other new $\mathrm{No}$ toraja species from New Zealand presently under description by Last et al., are herein described as four new species. They differ from species of the genus Brochiraja in lacking the bifurcate thorn on the snout tip (Last \& McEachran 2006), and from the species of the genus Insentiraja by a shorter snout, small fleshy process at snout tip, and less expanded nasal capsules (Yearsley \& Last 1992; McEachran \& Last 2008).

\section{METHODS}

The descriptive format follows Last et al. (2008) and Séret \& Last (2009). The abbreviations for institution names follow Leviton et al. (1985). In the species descriptions, morphometric proportions and meristic values are given first for the holotype, followed by ranges for the paratypes in brackets.

\section{ABBREVIATIONS}

MNHN Muséum national d'Histoire naturelle, Paris;

NMNZ Museum of New Zealand Te Papa Tongarewa, Wellington;

TL total length.

\section{SYSTEMATIC ACCOUNT}

Family ARHYNCHOBATIDAE Fowler, 1934 Genus Notoraja Ishiyama, 1958

Notoraja alisae n. sp.

(Figs 1-8; Tables 1, 3)

Rajidae NG sp. 9 - Last in Williams et al. 2006: listed in appendix 1, p. 36; 4 colour photos in Appendix 8, p. 6, of female $479 \mathrm{~mm}$ TL (NMNZ P 39619).

HoLOTYPE. - MNHN 1997-3598, adult male 515 mm TL, cruise HALIPRO 1, R/V Alis, stn CH876, northern Norfolk Ridge, $23^{\circ} 10.41^{\prime}$ S, $166^{\circ} 49.16^{\prime} \mathrm{E}, 870 \mathrm{~m}$ depth, 31.III.1994, bottom trawl.

PARATYPES. — 2 specimens. MNHN 1977-3599, male $340 \mathrm{~mm}$ TL, cruise HALIPRO 1, R/V Alis, stn CH876, $23^{\circ} 10.41^{\prime} \mathrm{S}, 166^{\circ} 49.16^{\prime} \mathrm{E}, 870 \mathrm{~m}$ depth, 31.III.1994, bottom trawl. - MNHN 1997-3600, female $492 \mathrm{~mm} \mathrm{TL}$, cruise HALIPRO 2, R/V Tangaroa, stn BT02, northern Norfolk Ridge, $23^{\circ} 16^{\prime}$ S, $167^{\circ} 49^{\prime} \mathrm{E}, 1025 / 1049 \mathrm{~m}$ depth, 5.XI.1996, bottom trawl. 


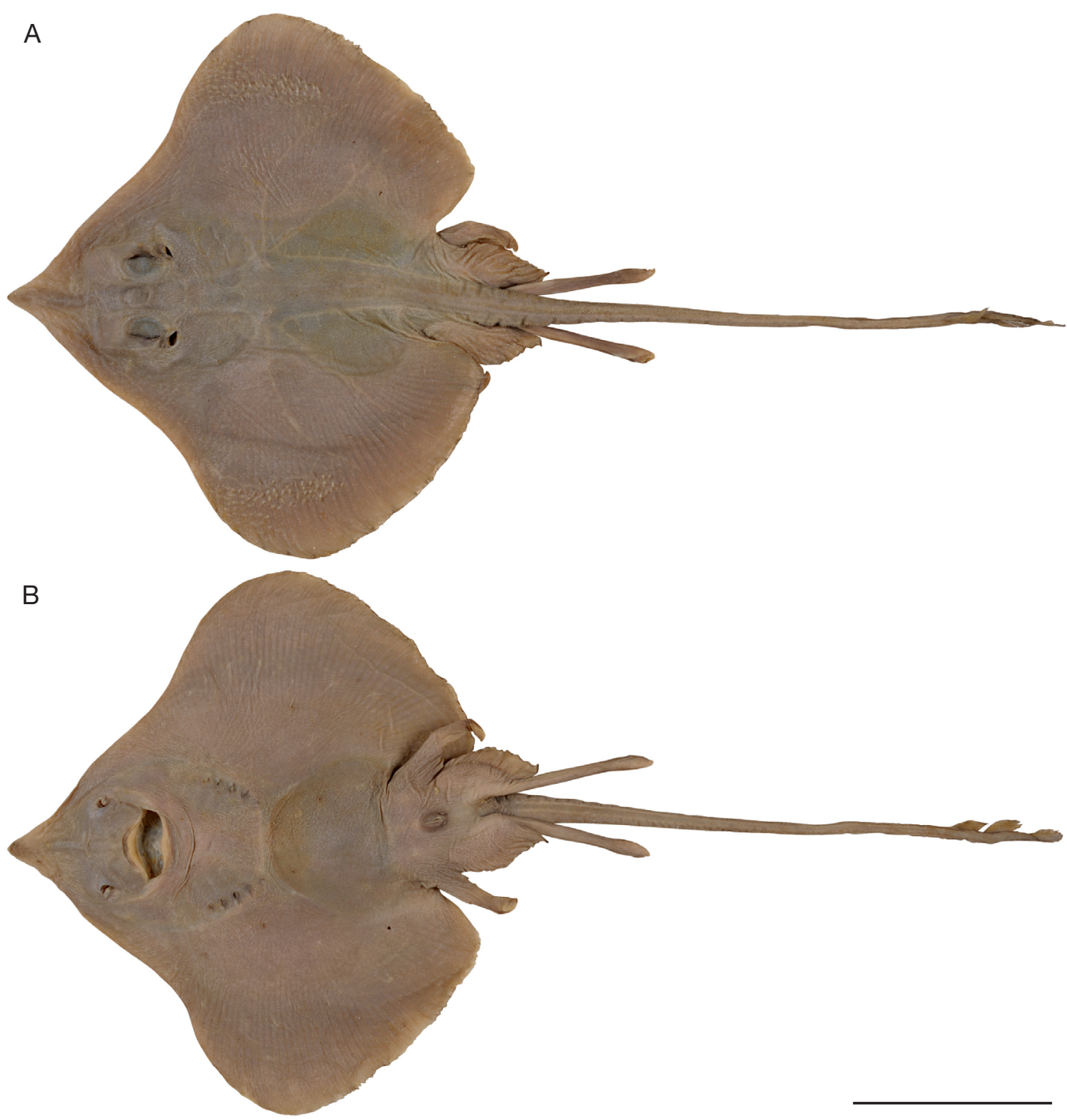

FIG. 1. - Notoraja alisae n. sp., holotype (MNHN 1997-3598, male adult 515 mm TL): A, dorsal surface; B, ventral surface. Scale bar: $10 \mathrm{~cm}$.

ADDITIONAL MATERIAL. -4 dark specimens. MNHN 1997-3601, adult male 533 mm TL, cruise HALIPRO 2, R/V Tangaroa, stn BT43, Norfolk Ridge, Seamount “Désespoir", 2541'S, 167²12'E, 1030/1320 m depth, bottom trawl, 15.XI.1996. - MNHN 1997-3597, female $545 \mathrm{~mm}$ TL, MUSORTOM 8, R/V Alis, Vanuatu, stn CP1008, 1853.29'S, 168 52.65’E, 919/1000 m depth, beam trawl, 25.IX.1994. - NMNZ P 39619, female $479 \mathrm{~mm}$ TL, NORZANZ cruise, R/V Tangaroa, stn 155, southern Norfolk Ridge, 34²34.81'S, 168 57.79'E, 813/1000 m depth, bottom trawl, 4.VI.2003. - MNHN 2003-1780, adult male $460 \mathrm{~mm}$ TL, NORFANZ cruise, R/V Tangaroa, stn 159, southern Norfolk Ridge, $35^{\circ} 8.13$ 'S, $169^{\circ} 28.37^{\prime} \mathrm{E}, 868 / 972 \mathrm{~m}$ depth, bottom trawl, 4.VI.2003.

Distribution. - Only known from the northern sector of the Norfolk Ridge (New Caledonian EEZ) from 870 to $1049 \mathrm{~m}$ depth. The dark form exhibits a 
TABLE 1. - Morphometrics for the pale and dark specimens of Notoraja alisae n. sp.

\begin{tabular}{|c|c|c|c|c|c|c|}
\hline & \multicolumn{3}{|c|}{ Notoraja alisae n. sp. pale } & \multicolumn{3}{|c|}{ Notoraja alisae n. sp. dark } \\
\hline & $\begin{array}{c}\text { MNHN } \\
\text { 1997-3598 } \\
\text { male adult } \\
\text { holotype }\end{array}$ & $\begin{array}{c}\text { MNHN } \\
1997-3600 \\
\text { female } \\
\text { paratype }\end{array}$ & $\begin{array}{c}\text { MNHN } \\
1997-3599 \\
\text { male juvenile } \\
\text { paratype }\end{array}$ & $\begin{array}{c}\text { MNHN } \\
1997-3601 \\
\text { male adult }\end{array}$ & $\begin{array}{c}\text { MNHN } \\
1997-3597 \\
\text { female }\end{array}$ & $\begin{array}{c}\text { MNNZ } \\
\text { P } 39619 \\
\text { female }\end{array}$ \\
\hline Total length (mm) & 515 & 492 & 340 & 533 & 545 & 479 \\
\hline Disc width & 51.7 & 55.5 & 50.9 & 53.7 & 55.2 & 54.5 \\
\hline Disc length (direct) & 45.0 & 45.7 & 43.8 & 47.8 & 47.7 & 46.3 \\
\hline Snout to maximum width & 25.2 & 27.4 & 26.0 & 28.1 & 29.9 & 24.4 \\
\hline Snout length (preorbital direct) & 12.0 & 12.3 & 11.5 & 12.7 & 12.4 & 12.1 \\
\hline Snout to spiracle & 15.6 & 15.6 & 14.5 & 16.3 & 15.1 & 15.3 \\
\hline Head (dorsal length) & 19.0 & 18.8 & 17.1 & 19.3 & 18.5 & 18.6 \\
\hline Orbit diameter & 4.5 & 4.0 & 4.5 & 4.3 & 4.2 & 4.4 \\
\hline Orbit and spiracle length & 5.4 & 5.4 & 5.1 & 5.3 & 5.1 & 5.5 \\
\hline Spiracle length (main pore) & 1.9 & 2.5 & 2.1 & 2.4 & 2.5 & 2.6 \\
\hline Distance between orbits & 3.3 & 3.6 & 3.7 & 3.8 & 3.6 & 3.5 \\
\hline Distance between spiracles & 6.4 & 6.7 & 6.2 & 6.5 & 6.5 & 6.5 \\
\hline Distance-snout to cloaca & 39.2 & 39.4 & 37.7 & 41.1 & 41.7 & 40.0 \\
\hline Cloaca to D1 & 47.0 & 46.1 & 48.5 & 43.9 & 43.7 & 44.8 \\
\hline Cloaca to D2 & 50.9 & 51.0 & 52.1 & 47.7 & 47.9 & 49.0 \\
\hline Cloaca to caudal origin & 58.6 & 53.3 & 57.9 & 51.2 & 52.7 & 53.3 \\
\hline Distance-cloaca to caudal-fin tip & 59.6 & 57.1 & 60.3 & 56.8 & 56.9 & 58.0 \\
\hline Ventral snout length (pre upper jaw) & 11.7 & 13.0 & 11.1 & 12.3 & 12.2 & 13.1 \\
\hline Prenasal length & 10.4 & 10.7 & 9.8 & 10.5 & 10.6 & 10.9 \\
\hline Ventral head length (to fifth gill) & 24.3 & 24.1 & 23.2 & 25.5 & 23.6 & 24.7 \\
\hline Mouth width & 7.0 & 6.5 & 6.1 & 6.4 & 6.7 & 6.3 \\
\hline Distance between nostrils & 7.2 & 7.5 & 7.0 & 7.3 & 7.5 & 8.0 \\
\hline Nasal curtain length & 4.1 & 4.6 & 4.0 & 4.9 & 4.2 & 4.3 \\
\hline Nasal curtain (total width) & 8.6 & 9.2 & 8.1 & 9.8 & 8.8 & 8.9 \\
\hline Nasal curtain (min width) & 4.8 & 5.0 & 5.0 & 5.6 & 4.7 & 5.3 \\
\hline Nasal curtain (lobe width) & 2.5 & 2.4 & 2.1 & 2.7 & 2.4 & 2.3 \\
\hline Width of first gill opening & 0.9 & 1.2 & 0.8 & 1.4 & 1.2 & 1.2 \\
\hline Width of fifth gill opening & 0.7 & 1.0 & 0.6 & 0.9 & 1.0 & 1.0 \\
\hline Distance between first gill openings & 10.9 & 13.0 & 12.4 & 11.9 & 12.9 & 11.9 \\
\hline Length of posterior pelvic lobe & 15.4 & 14.0 & 13.6 & 16.8 & 15.2 & 15.0 \\
\hline Pelvic base width & 8.4 & 10.1 & 8.0 & 8.2 & 9.3 & 9.8 \\
\hline Tail at axil pelvic fins (width) & 3.0 & 3.7 & 3.8 & 3.3 & 3.5 & 3.2 \\
\hline Tail at axil pelvic fins (height) & 2.0 & 2.3 & 2.2 & 2.1 & 2.2 & 2.1 \\
\hline Tail at midlength (width) & 1.2 & 1.4 & 1.6 & 1.4 & 1.6 & 1.4 \\
\hline Tail at midlength (height) & 1.2 & 1.2 & 1.1 & 1.1 & 1.1 & 1.3 \\
\hline Tail at D1 origin (width) & 1.1 & 1.1 & 1.0 & 1.5 & 1.2 & 1.1 \\
\hline Tail at D1 origin (height) & 0.7 & 0.8 & 0.7 & 0.8 & 0.7 & 0.9 \\
\hline D1 base length & 2.7 & 3.1 & 3.4 & 3.2 & 3.1 & 3.7 \\
\hline D1 height & 1.3 & 1.5 & 1.0 & 1.4 & 1.4 & 1.4 \\
\hline D1 origin to caudal-fin tip & 12.0 & 10.6 & 11.6 & 13.0 & 13.4 & 13.0 \\
\hline D2 origin to caudal-fin tip & 8.4 & 7.2 & 7.6 & 9.5 & 9.4 & 8.8 \\
\hline Caudal-fin length & 4.2 & 3.8 & 3.4 & 5.3 & 4.1 & 4.4 \\
\hline Interdorsal & 0.7 & 0.9 & 1.4 & 0.5 & 0.9 & 0.8 \\
\hline
\end{tabular}




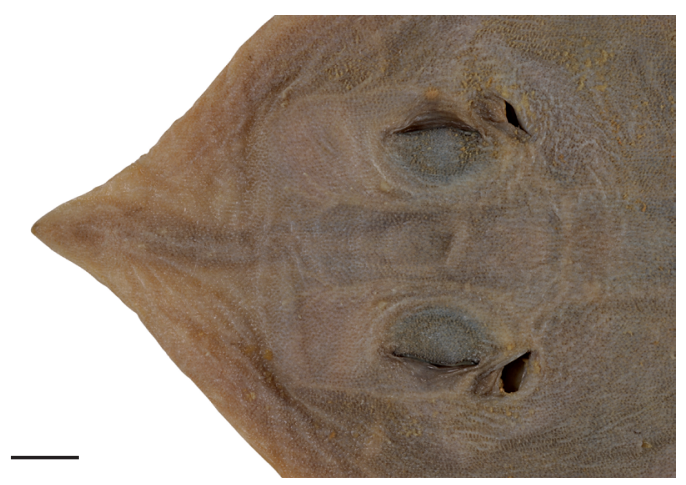

FIG. 2. - Dorsal head of Notoraja alisae n. sp., holotype (MNHN 1997-3598, male adult $515 \mathrm{~mm}$ TL). Scale bar: $1 \mathrm{~cm}$.

wider latitudinal distribution, from the southern Norfolk Ridge (35 $8^{\prime}$ 'S) in New Zealand's EEZ to Espiritu Santo in Vanuatu (c. 18 $8^{\circ} 53^{\prime}$ S) (Fig. 18).

Eтymology. - From the name of the French research vessel Alis of the Institut de Recherche pour le Développement (IRD) in Nouméa, with which numerous exploratory cruises have been performed in New Caledonian EEZ in the last decades; the name of the ship Alis came from the name of a local wind.

DiAGNOSIs. - A medium-size species of Notoraja with the following combination of characters: disc wider than long, width 50.9-55.5\% TL, length $43.8-45.7 \% \mathrm{TL}$; dorsal head length $17.1-19.0 \% \mathrm{TL}$; interspiracular distance $6.2-6.7 \%$ TL, internasal distance 7.0-8.5\% TL, preorbital length 2.7-3.1 times orbit length and 3.4-3.6 interorbital; tail width at pelvic-fin axil 1.5-1.6 times its height; single rudimentary preorbital thorn; dorsal and ventral surfaces of disc entirely velvety, covered with fine denticles; tail long and slender, entirely velvety and without enlarged thorns; lateral tail folds variably expanded posteriorly, their width sometimes greater than tail width at level of second dorsal fin; nasal lobes expanded, width of nasal curtain $8.1-9.8 \% \mathrm{TL}$; anterior pelvic-fin lobe shorter that posterior lobe; dorsal and ventral surfaces pale greyish brown; total pectoral-fin radials 63; monospondylous centra 24-25, total diplospondylous centra 112-117, total centra 136-142.

\section{DESCRIPTION}

Disc heart-shaped (more so in adult male than female and young), 1.15 times as broad as long in male holotype (1.16-1.21 in paratypes); maximum angle in front of spiracles $83^{\circ}\left(98-99^{\circ}\right)$; anterior margin slightly concave on either side of tip of

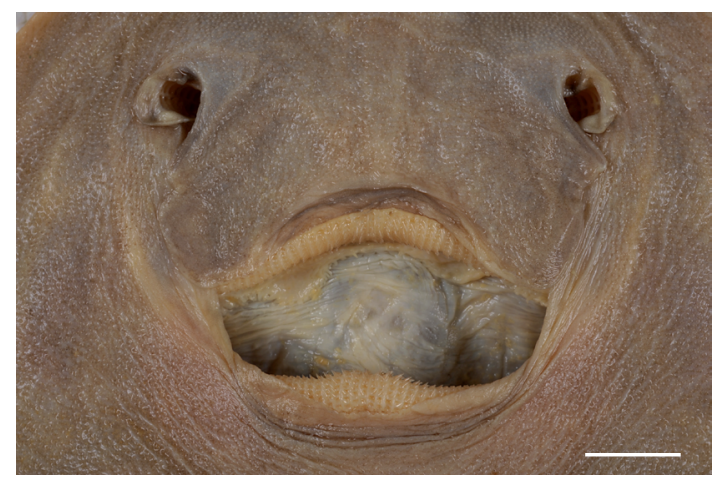

FIG. 3. - Oronasal region of Notoraja alisae n. sp., holotype (MNHN 1997-3598, male adult $515 \mathrm{~mm}$ TL). Scale bar: $1 \mathrm{~cm}$.

snout, slightly convex from anterior extension of propterygium to anterior margin of orbit, concave to level of spiracle; outer corner broadly rounded; posterolateral margin moderately convex in males; anterolateral margins of disc very slightly undulate in female and juvenile. Axis of greatest width $56 \%(59-60 \%)$ of disc length. Preorbital snout length 2.66 (2.58-3.09) times orbit length, 3.64 (3.11-3.38) times interorbital width; preoral snout length 1.63 (1.58-1.74) times internarial distance. Orbit diameter 1.37 (1.09-1.20) times interorbital distance, and 2.32 (1.59-2.08) times length of spiracles. Nasal lobes moderately expanded and rounded, posterior margin shortly and flabby fringed. Mouth relatively wide, its width more than 66\% of maximum width of nasal curtain. Upper jaw of male slightly indented at symphysis (not indented in female and moderately arched); upper and lower jaws slightly arched on either side of symphysis. Teeth with acutely pointed cusps and arranged in parallel rows in mature male holotype (plate-like with short cusps and arranged in quincunx in female and juvenile male paratypes). Distance between first gill slits 1.51 (1.73-1.77) times larger than distance between nostrils; distance between fifth gill slits 1.00 (1.21-1.29) times larger than distance between nostrils.

Pelvic fins deeply incised with lobes connected by radials and membranes, anterior lobe moderately long, reaching to about posterior third of posterior lobe (further in paratypes), finger-like with blunt 

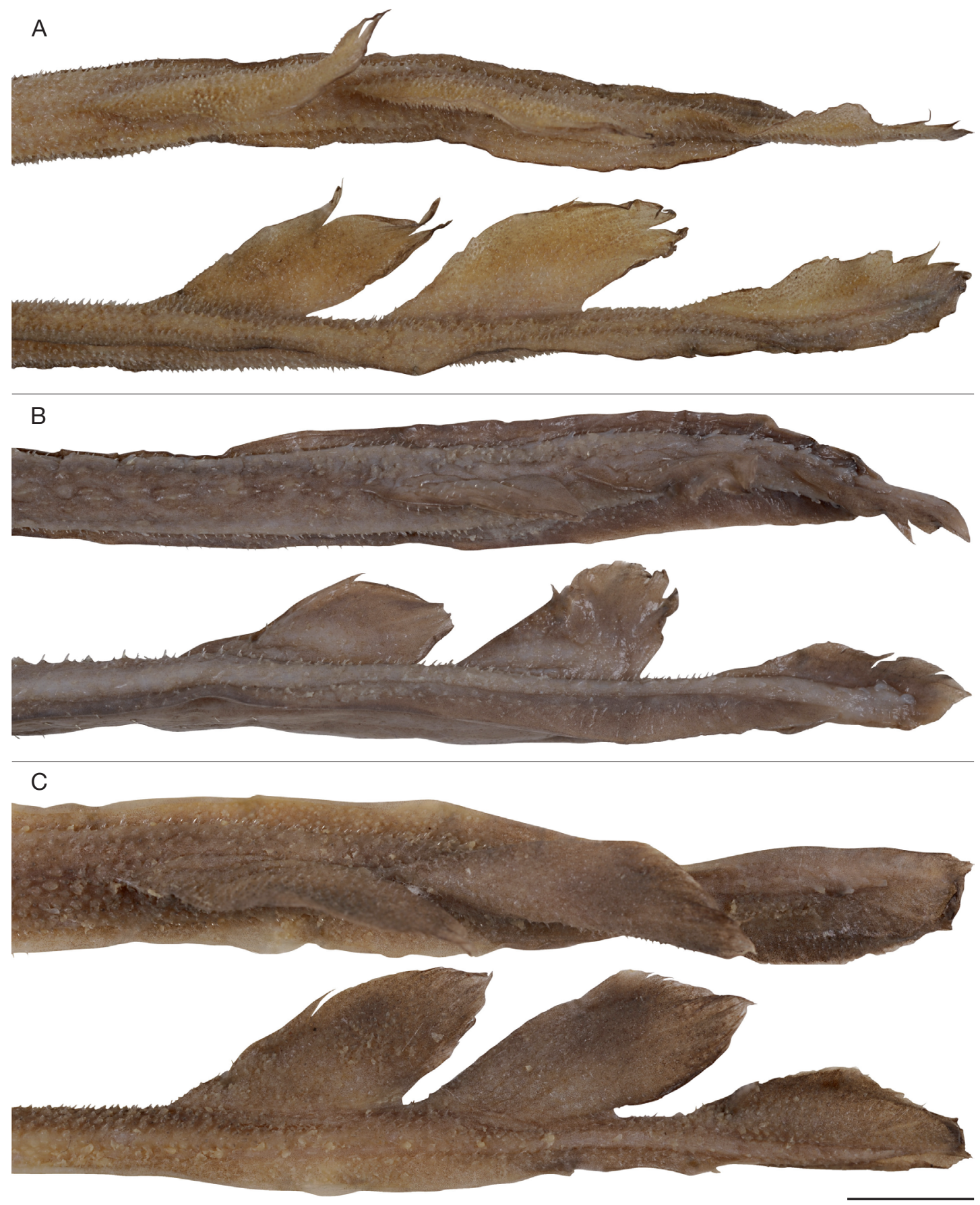

FIG. 4. - Lateral and dorsal views of tip of tail of: A, Notoraja alisae n. sp. (holotype MNHN 1997-3598); B, N. inusitata n. sp. (MNHN 2008-1638); C, N. fijiensis n. sp. (holotype MNHN 1999-0450); D, N. longiventralis n. sp. (holotype MNHN 1999-0449). Scale bar: 1 cm. 

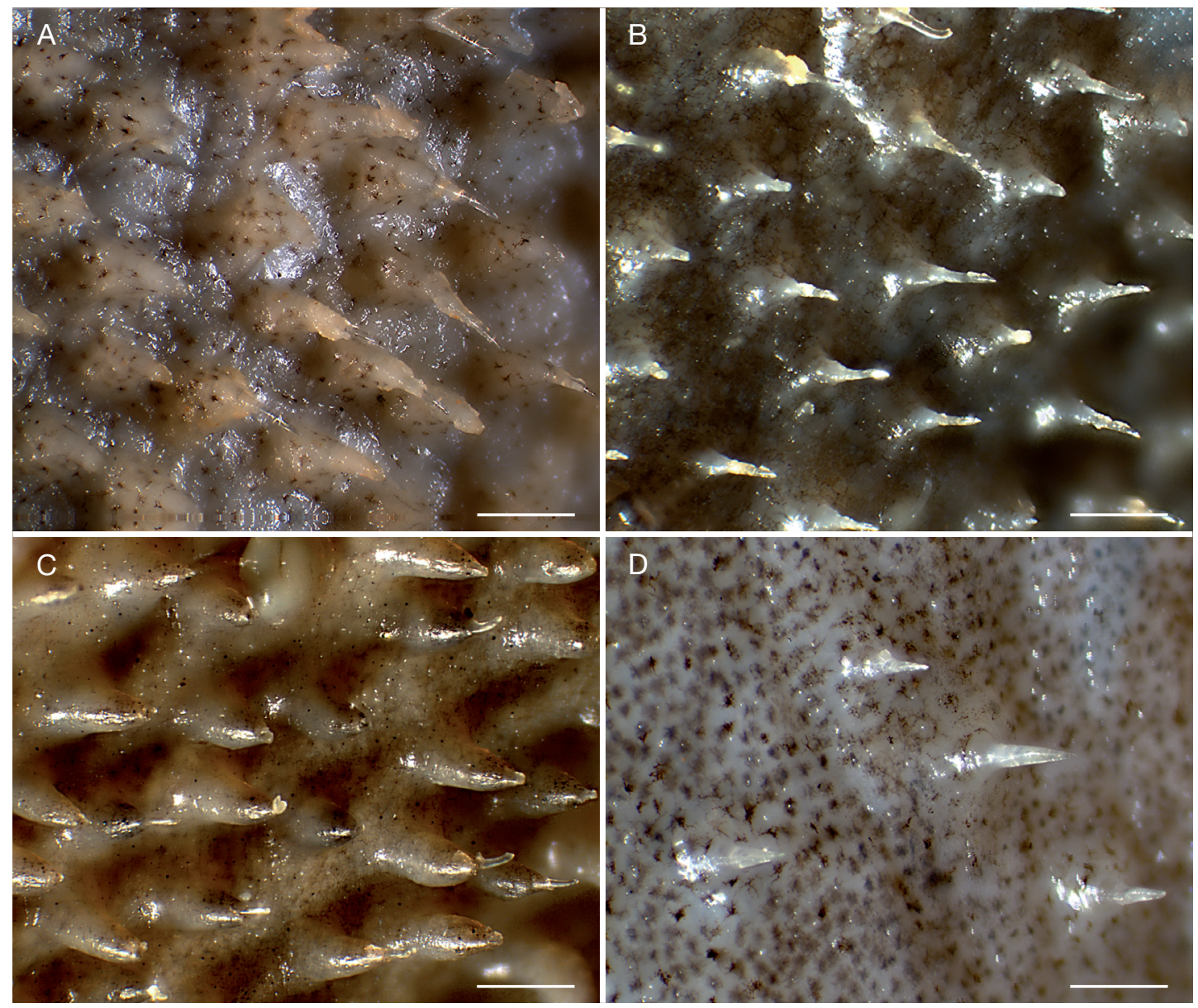

FIG. 5. - Dorsal dermal denticles of: A, Notoraja alisae n. sp. (holotype MNHN 1997-3598); B, N. longiventralis n. sp. (holotype MNHN 1999-0449); C, N. fijiensis n. sp. (holotype MNHN 1999-0450); D, N. inusitata n. sp. (MNHN 2008-1638). Scale bars: $1 \mathrm{~cm}$.

tip; posterior lobe with convex lateral margins, its posterior margin crenate due to extension of posterior radials. Tail narrow at base, variably depressed over length; strongly convex dorsally, slightly convex ventrally; tapering gradually posteriorly; tail width at axils of pelvic fins 2.44 (2.34-2.60) times width at its midlength, 2.65 (3.38-3.71) times its width at dorsal-fin origin respectively; length from rear of cloaca 1.52 (1.45-1.60) times distance from tip of snout to rear of cloaca; width at first dorsal origin $1.53(1.62-1.71)$ times height at axils of pelvic fin; width at first dorsal-fin origin 1.73 (1.431.54) times its height; lateral skin folds originating near midlength of tail, extending to distal half of epichordal caudal-fin lobe; folds slightly broadening distally (more so in paratypes), but always narrower than tail width. Dorsal fins of similar shape and size; rather short and moderately tall with evenly convex anterior margins, straight or slightly convex posterior margins and a pointed rear tips; separated by a short interspace, $41 \%$ (23-36\%) length of first dorsal-fin base. Epichordal caudal-fin lobe developed, separated by narrow interspace from and distinctly longer than second dorsal-fin base; hypochordal caudal lobe very low, originating near end of lateral fold, confluent with epichordal lobe.

Both dorsal and ventral surfaces entirely covered with fine, densely spaced, dermal denticles; denticles 


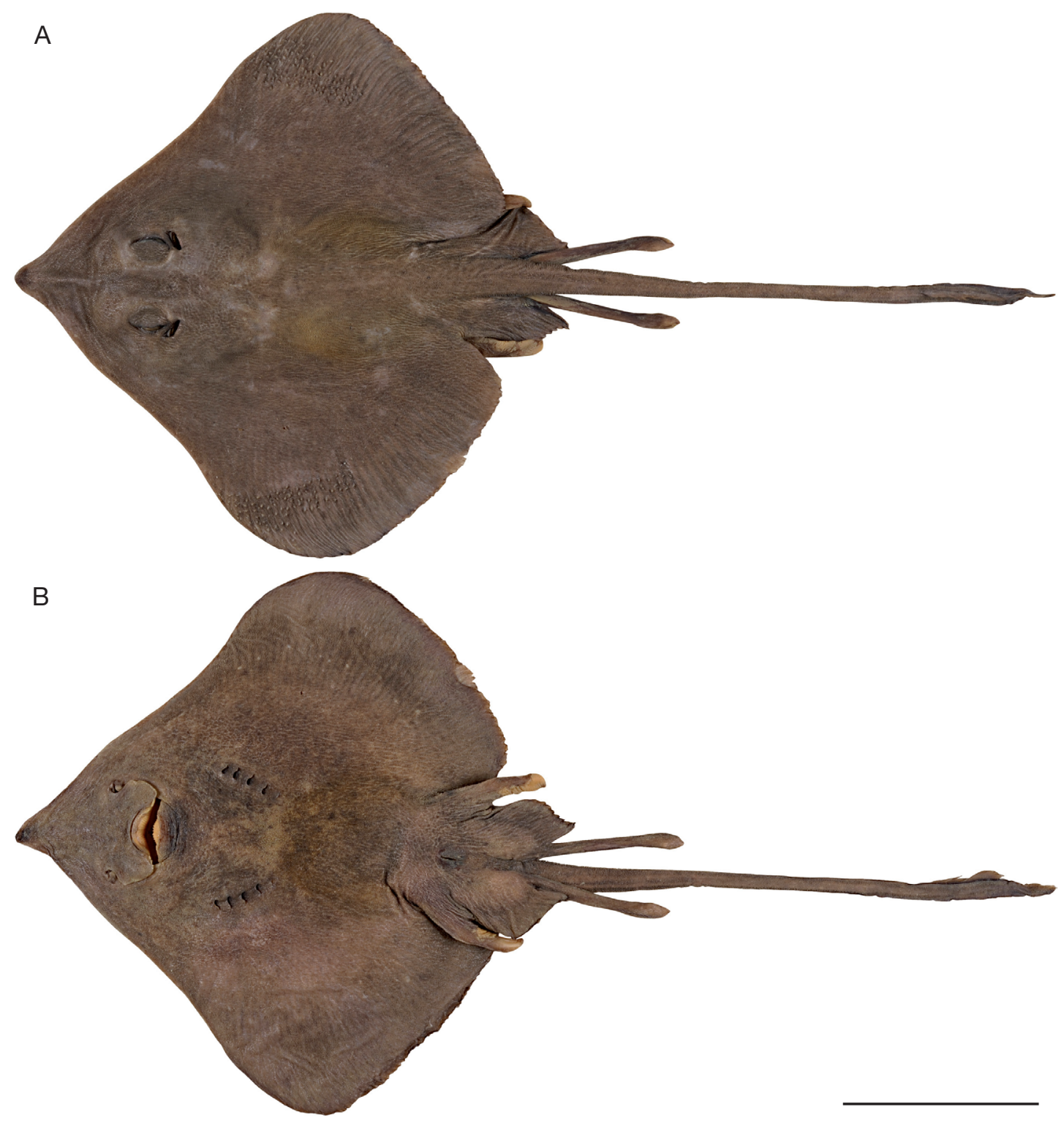

FIG. 6. - Notoraja alisae n. sp., dark form (MNHN 1997-3601, male adult 533 mm TL): A, dorsal surface; B, ventral surface. Scale bar: $10 \mathrm{~cm}$.

bristle-like, erect, with almost straight pointed crowns. Single greatly reduced preorbital thorn (even very small in juvenile). Tail totally velvety, lacking enlarged thorns; median thorns very small, confined mainly to anterior tail, barely taller than largest denticles adjacent. Alar thorns in three or four irregular rows; posteromedially oriented, with elongated bases, oblique slightly curved crowns, exposed on integument. Malar thorn patch small, on outer anterior margin and merging with those of alar patch; noticeably larger than adjacent denticles, with oval conical base and fine curved cusp. 


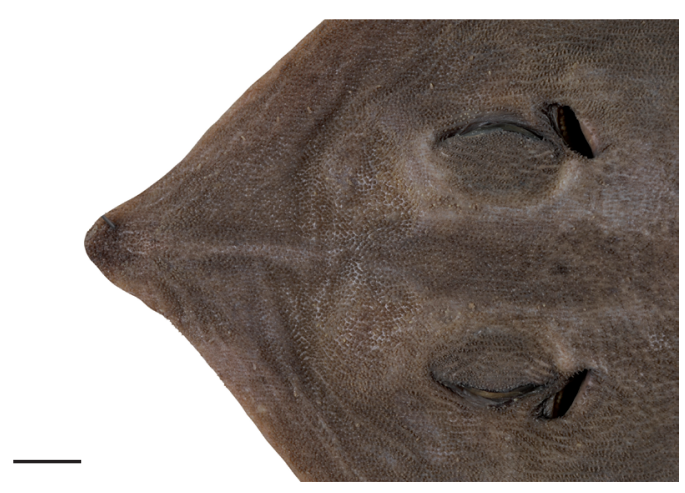

FIG. 7. - Dorsal head of Notoraja alisae n. sp., dark form (MNHN 1997-3601, male adult $533 \mathrm{~mm}$ TL). Scale bar: $1 \mathrm{~cm}$.

Claspers long and very slender, glans depressed, but little expanded; with inner dorsal components slit, cleft and pseudorhipidion, and inner ventral components pela, projection and spike. Claspers partially covered with lines of very fine dermal denticles.

Tooth rows in upper jaw 38 in male holotype (34-43 in paratypes); lower jaw 40 (33-38). Pectoral propterygial radials 28 (28); mesopterygial radials 11-12 (11-12); metapterygial radials 22-23 (21-24); total radials 62 (61-63). Monospondylous centra 24 (24-25); diplospondylous predorsal centra 77 (78-82); predorsal centra 101 (102-107); caudal centra 35 (35-37); total diplospondylous centra 112 (115-117); total centra 136 (139-142).

\section{Colour (in preservative)}

Dorsal surface plain pale greyish brown. Ventral surface lighter, yellowish with faint whitish spots at level of pores of the lateral line system.

\section{Size}

Males reach at least $515 \mathrm{~mm}$ TL (adult male holotype), and females to at least $545 \mathrm{~mm}$ TL (based on dark female from Vanuatu, MNHN 1997-3597).

\section{REMARKS}

This velcro skate is well represented by specimens. A group of unusually dark individuals are tentatively assigned to Notoraja alisae n. sp., but were excluded from the type series (cf. additional material; Figs 6-8; Tables 1,3) pending further investigation. They closely

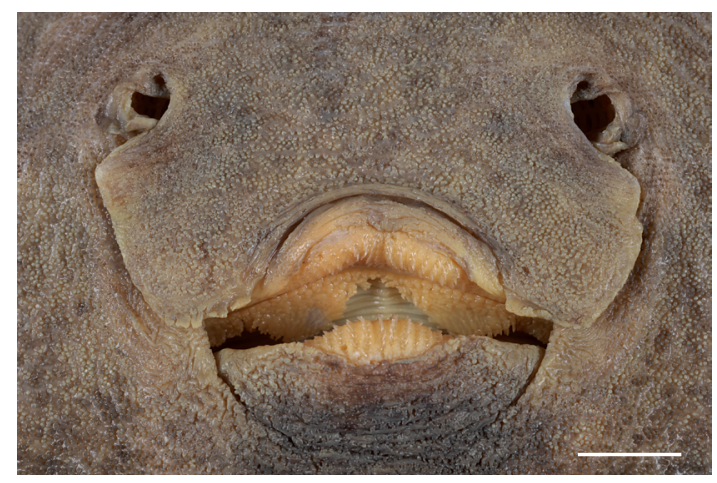

FIG. 8. - Oronasal region of Notoraja alisae n. sp., dark form (MNHN 1997-3601, male adult $533 \mathrm{~mm}$ TL). Scale bar: $1 \mathrm{~cm}$.

resemble the typical pale form of this species, except for their darker colouration and slight morphometric differences. These dark specimens are: darker dorsally (plain dark greyish with darker eyes, posterior pelvicfin lobes and lateral tail folds); the ventral surface is dark grey, particularly on the central part of disc; their pale ventral pores are more pronounced, forming lines of light spots along branches of the lateral line system; their disc is slightly longer (46.6-47.8\% TL vs $43.8-45.7 \%$ TL); precloacal length slightly longer (40.0-41.7\% TL vs 37.7-39.4\% TL); tail somewhat shorter (distance from the cloaca to the first dorsal-fin origin 43.7-44.8\% TL vs 46.1-48.5\% $\mathrm{TL}$, to the second dorsal-fin origin $47.7-49.0 \% \mathrm{TL}$ vs 50.9-52.1\% TL, to the caudal-fin origin 51.2-53.3\% TL vs $53.3-58.6 \% \mathrm{TL}$, and to tail tip $56.8-58.0 \%$ TL vs $57.1-60.3 \% \mathrm{TL}$ ). Although the tail is shorter, its predorsal length is longer (distance first dorsal-fin origin to tip of tail $4.1-5.3 \% \mathrm{TL}$ vs $3.4-4.2 \% \mathrm{TL}$ ). No meristic differences nor differences in the external components of the clasper were found.

Squamation is similar in both pale and dark specimens, however a dark mature male (MNHN 19973601) has coarser dermal denticles arranged in small, irregular patches and lines (similar, but less pronounced, lines are present on the posterior pectoral fins of the holotype), and the preorbital thorns are not apparent in a dark female (MNHN 1997-3597). Pending collection and examination of more specimens of the dark form, we consider these slight differences to be intraspecific variations of $N$. alisae n. sp. 


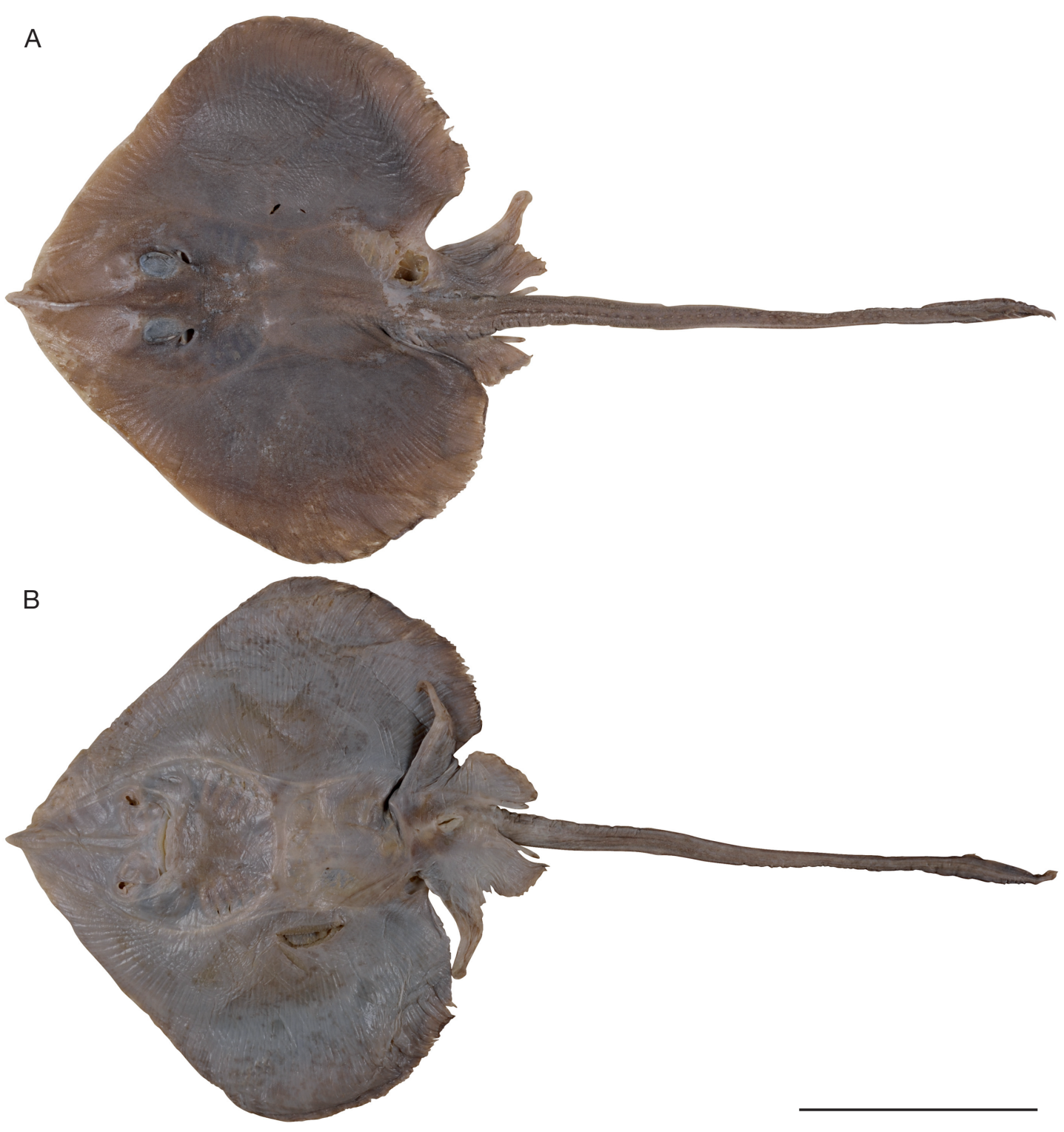

FIG. 9. - Notoraja inusitata n. sp., holotype (MNHN 2008-1638, male juvenile 444 mm TL): A, dorsal surface; B, ventral surface. Scale bar: $10 \mathrm{~cm}$.

Notoraja inusitata n. sp.

(Figs 9-12; Tables 2, 3)

Notoraja sp. 2 - Séret in Fricke et al. (2011): listed p. 5.

HolOTYPE. - MNHN 2008-1638 (field number DHS 733, tissue sample ICTI-001845), male juvenile $444 \mathrm{~mm}$ TL, SANTO expedition, R/V Alis, Vanuatu, Espiritu
Santo Island, Big Bay, stn 107, 14'58.6'S, 166 $52.5^{\prime} \mathrm{E}$, 807/844 m depth, beam trawl, 16.X.2006.

Distribution. - Known only from Big Bay, Espiritu Santo (Vanuatu), from 807 to $844 \mathrm{~m}$ depth (Fig. 18).

ETYMOLOGY. - In the absence of an adult male, the generic placement of this ray initially proved to be problematic; its head and disc morphology resemble some 


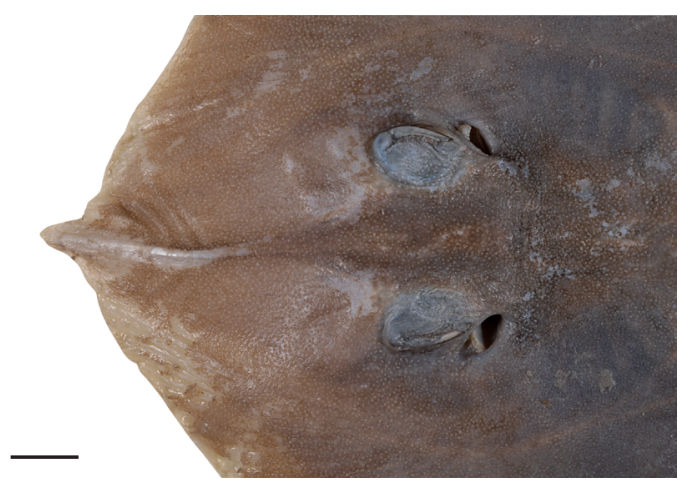

FIG. 10. - Dorsal head of Notoraja inusitata n. sp., holotype (MNHN 2008-1638, male juvenile $444 \mathrm{~mm}$ TL). Scale bar: $1 \mathrm{~cm}$.

species of Sinobatis Hulley, 1973, Bathyraja Ishiyama, 1958 and Insentiraja. Hence, we have used the Latin "inusitatus" (unusual, strange) to allude to the strange appearance of this ray.

DiAGNOSIS. - A species of Notoraja (probably of medium size as male $440 \mathrm{~mm}$ TL is juvenile) with the following combination of characters: disc broadly heart-shaped, snout tip projecting as a short blunted triangle, single preorbital thorn; dorsal surface of disc entirely velvety, covered with very fine denticles; ventral surface of disc naked; tail long and tapering from base to first dorsal fin, slightly expanded at level of dorsal fins; tail entirely pricked except for the ventral base, an irregular mediodorsal row of small denticles on tail; lateral tail folds expanded at level of dorsal and caudal fins, but width less than tail width; low epichordal caudal-fin lobe; nasal lobes not greatly expanded, width of nasal curtain $7.7 \%$ TL; mouth relatively narrow, its width less than $66 \%$ of maximum width of nasal curtain and $5.1 \% \mathrm{TL}$; anterior and posterior pelvic-fin lobes subequal in length; dorsal surface pale greyish brown, ventral surface whitish. Total pectoral-fin radials 74 , monospondylous centra 27 , total diplospondylous centra 116, total centra 143 .

\section{DESCRIPTION}

Disc broadly heart-shaped, 1.10 times as broad as long; maximum angle in front of spiracles $93^{\circ}$; snout tip projecting as a short blunt triangle, rostral cartilage clearly visible dorsally and ventrally, not concealed by thick skin; anterior margin of disc very weakly undulated, slightly and regularly convex from base of snout tip to level of spiracles; outer corner and posterior margins broadly rounded. Axis of greatest width $57 \%$ of disc length. Preorbital snout length

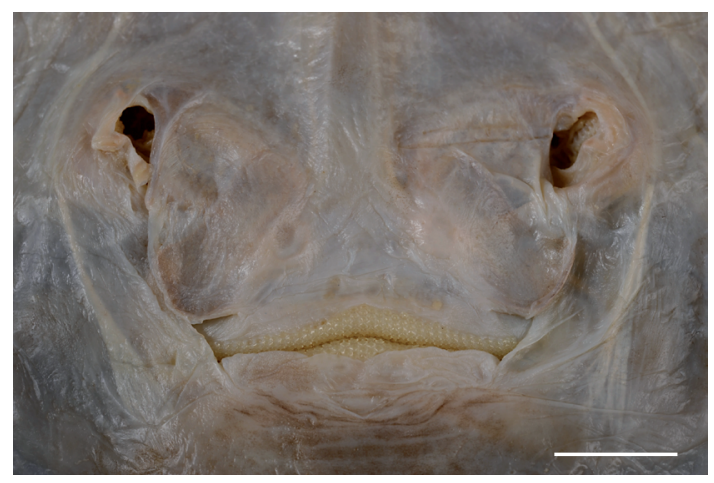

FIG. 11. - Oronasal region of Notoraja inusitata n. sp., holotype (MNHN 2008-1638, male juvenile $444 \mathrm{~mm}$ TL). Scale bar: $1 \mathrm{~cm}$.

3.72 times orbit length, 3.73 times interorbital width; preoral snout length 2.14 times internarial distance. Orbit diameter subequal to interorbital distance, and 1.76 times length of spiracles. Nasal lobes not greatly expanded and rounded, posterior margin weakly and coarsely fringed. Mouth relatively small, its width only about $66 \%$ of maximal width of nasal curtain. Upper and lower jaws weakly arched on either side of symphysis. Teeth plate-like, with short cusps and arranged in quincunx. Distance between first gill slits 1.57 times larger than between nostrils; distance between fifth gill slits subequal to internarial distance.

Pelvic fins deeply incised with lobes connected by radials and membranes, anterior lobe long, subequal in length to posterior lobe; posterior lobe with convex lateral margins, posterior margin crenate due to extension of posterior radials. Tail long and tapering from base to first dorsal fin, slightly expanded at level of dorsal fins, then tapering to tail tip; tail only weakly depressed at its base, almost oval in cross-section; more depressed from midlength, only weakly convex ventrally; width at axils of pelvic fins 1.83 times width at midlength of tail, and 2.74 times width at dorsal-fin origin respectively; length from rear of cloaca 1.37 times distance from tip of snout to rear of cloaca; lateral skin folds originating anteriorly to tips of posterior pelvic-fin lobes, extending to distal half to distal fourth of epichordal caudal-fin lobe and broadening distally from about level of first dorsal fin to 
TABLE 2. - Morphometrics for the holotypes and paratypes of Notoraja inusitata n. sp. (MNHN 2008-1638), Notoraja fijiensis n. sp. (MNHN 1999-0450 to 453), and Notoraja longiventralis n. sp. (MNHN 1999-0449, MNHN 2008-1389).

\begin{tabular}{|c|c|c|c|c|c|c|c|}
\hline & \multicolumn{4}{|c|}{ Notoraja fijiensis $\mathrm{n} . \mathrm{sp}$. } & \multirow{2}{*}{$\begin{array}{l}\text { N. inusitata } \\
\text { n. sp. } \\
\text { MNHN }\end{array}$} & \multicolumn{2}{|c|}{$\begin{array}{l}\text { N. longiventralis } \\
\text { n. sp. }\end{array}$} \\
\hline & $\begin{array}{c}\text { MNHN } \\
1999-0450\end{array}$ & $\begin{array}{c}\text { MNHN } \\
1999-0452\end{array}$ & $\begin{array}{c}\text { MNHN } \\
1999-0453\end{array}$ & $\begin{array}{c}\text { MNHN } \\
1999-0451\end{array}$ & & $\begin{array}{c}\text { MNHN } \\
1999-0449\end{array}$ & $\begin{array}{c}\text { MNHN } \\
92008-1389\end{array}$ \\
\hline & $\begin{array}{l}\text { female } \\
\text { holotype }\end{array}$ & $\begin{array}{c}\text { male } \\
\text { juvenile } \\
\text { paratype }\end{array}$ & $\begin{array}{c}\text { female } \\
\text { paratype }\end{array}$ & $\begin{array}{c}\text { male } \\
\text { juvenile } \\
\text { paratype }\end{array}$ & $\begin{array}{c}\text { male } \\
\text { juvenile } \\
\text { holotype }\end{array}$ & $\begin{array}{c}\text { male } \\
\text { juvenile } \\
\text { holotype }\end{array}$ & $\begin{array}{c}\text { male } \\
\text { juvenile } \\
\text { paratype }\end{array}$ \\
\hline Total length $(\mathrm{mm})$ & 386 & 307 & 217 & 212 & 444 & 434 & 229 \\
\hline Disc width & 54.1 & 49.8 & 49.3 & 47.6 & 52.7 & 50.0 & 51.5 \\
\hline Disc length (direct) & 45.9 & 44.3 & 42.4 & 42.9 & 47.7 & 44.2 & 45.4 \\
\hline Snout to maximum width & 25.9 & 26.7 & 22.6 & 25.5 & 27.3 & 25.8 & 27.5 \\
\hline Snout length (preorbital direct) & 12.1 & 13.2 & 13.2 & 12.0 & 14.5 & 11.9 & 12.1 \\
\hline Snout to spiracle & 15.5 & 16.2 & 15.8 & 15.9 & 17.3 & 15.0 & 15.0 \\
\hline Head (dorsal length) & 18.4 & 19.3 & 18.3 & 18.8 & 18.9 & 17.6 & 17.7 \\
\hline Orbit diameter & 4.7 & 4.1 & 4.7 & 4.8 & 3.9 & 3.6 & 4.6 \\
\hline Orbit and spiracle length & 5.1 & 4.9 & 4.6 & 4.9 & 4.9 & 4.8 & 4.9 \\
\hline Spiracle length (main pore) & 2.3 & 2.1 & 1.5 & 1.8 & 2.2 & 2.4 & 1.9 \\
\hline Distance between orbits & 3.4 & 3.4 & 3.7 & 3.6 & 3.9 & 3.3 & 4.0 \\
\hline Distance between spiracles & 6.6 & 6.2 & 6.1 & 6.5 & 5.7 & 6.0 & 6.3 \\
\hline Distance-snout to cloaca & 38.9 & 37.9 & 35.0 & 37.6 & 41.4 & 38.5 & 38.8 \\
\hline Cloaca to D1 & 47.7 & 46.9 & 47.0 & 46.8 & 45.9 & 45.9 & 45.1 \\
\hline Cloaca to D2 & 51.0 & 51.8 & 50.7 & 47.2 & 49.5 & 49.8 & 49.9 \\
\hline Cloaca to caudal origin & 54.4 & 55.4 & 54.8 & 55.7 & 52.9 & 54.1 & 54.6 \\
\hline Distance-cloaca to caudal-fin tip & 58.5 & 60.6 & 60.8 & 58.5 & 56.8 & 59.2 & 61.1 \\
\hline Ventral snout length (pre upper jaw) & 13.3 & 14.6 & 13.2 & - & 15.4 & 13.2 & 13.2 \\
\hline Prenasal length & 10.2 & 11.4 & 10.9 & - & 12.1 & 10.4 & 10.5 \\
\hline Ventral head length (to fifth gill) & 24.5 & 24.3 & 22.9 & 23.6 & 25.9 & 23.6 & 23.2 \\
\hline Mouth width & 6.0 & 6.2 & 5.7 & - & 5.1 & 6.5 & 5.0 \\
\hline Distance between nostrils & 7.1 & 6.9 & 6.7 & - & 7.2 & 7.3 & 6.8 \\
\hline Nasal curtain length & 4.6 & 4.2 & 3.6 & - & 4.3 & 4.3 & 4.0 \\
\hline Nasal curtain (total width) & 8.3 & 8.0 & 7.3 & - & 7.7 & 7.6 & 8.0 \\
\hline Nasal curtain (min width) & 4.7 & 5.1 & 4.6 & - & 4.6 & 4.7 & 4.5 \\
\hline Nasal curtain (lobe width) & 2.1 & 1.9 & 1.7 & - & 1.8 & 1.7 & 2.3 \\
\hline Width of first gill opening & 0.8 & 1.0 & 0.9 & - & 1.0 & 1.1 & 0.7 \\
\hline Width of fifth gill opening & 0.5 & 0.6 & 0.7 & - & 0.7 & 0.9 & 0.5 \\
\hline Distance between first gill openings & 13.3 & 11.7 & 10.9 & - & 11.3 & 11.6 & 11.4 \\
\hline Distance between fifth gill openings & 8.8 & 6.3 & 7.4 & - & 7.0 & 7.8 & 7.0 \\
\hline Clasper (post cloacal length) & 0.0 & 6.6 & 0.0 & 7.3 & 6.7 & 8.5 & 12.0 \\
\hline Length of anterior pelvic lobe & 13.7 & 14.0 & 13.7 & 15.1 & 13.5 & 14.8 & 15.0 \\
\hline Length of posterior pelvic lobe & 15.6 & 13.2 & 12.1 & 13.6 & 14.0 & 12.9 & 13.0 \\
\hline Pelvic base width & 9.4 & 7.2 & 7.6 & 7.7 & 7.5 & 7.3 & 7.9 \\
\hline Tail at axil pelvic fins (width) & 3.9 & 3.0 & 2.8 & 3.3 & 3.4 & 3.3 & 3.3 \\
\hline Tail at axil pelvic fins (height) & 2.6 & 2.2 & 1.8 & 2.0 & 2.4 & 2.2 & 2.3 \\
\hline Tail at midlength (width) & 1.6 & 1.5 & 1.4 & 1.3 & 1.8 & 1.3 & 1.7 \\
\hline Tail at midlength (height) & 1.3 & 1.2 & 1.0 & 1.1 & 1.6 & 1.0 & 1.3 \\
\hline Tail at D1 origin (width) & 1.6 & 1.1 & 1.1 & 1.1 & 1.2 & 1.1 & 0.8 \\
\hline
\end{tabular}


TABLE 2. - Continuation.

\begin{tabular}{|c|c|c|c|c|c|c|c|}
\hline & \multicolumn{4}{|c|}{ Notoraja fijiensis n. sp. } & \multirow{2}{*}{$\begin{array}{l}\text { N. inusitata } \\
\text { n. sp. } \\
\text { MNHN } \\
12008-1638\end{array}$} & \multicolumn{2}{|c|}{$\begin{array}{c}\text { N. longiventralis } \\
\text { n. sp. }\end{array}$} \\
\hline & $\begin{array}{c}\text { MNHN } \\
1999-0450\end{array}$ & $\begin{array}{c}\text { MNHN } \\
1999-0452\end{array}$ & $\begin{array}{c}\text { MNHN } \\
1999-0453\end{array}$ & $\begin{array}{c}\text { MNHN } \\
31999-0451\end{array}$ & & $\begin{array}{c}\text { MNHN } \\
\text { 1999-0449 }\end{array}$ & $\begin{array}{c}\text { MNHN } \\
92008-1389\end{array}$ \\
\hline & $\begin{array}{c}\text { female } \\
\text { holotype }\end{array}$ & $\begin{array}{c}\text { male } \\
\text { juvenile } \\
\text { paratype }\end{array}$ & $\begin{array}{c}\text { female } \\
\text { paratype }\end{array}$ & $\begin{array}{c}\text { male } \\
\text { juvenile } \\
\text { paratype }\end{array}$ & $\begin{array}{c}\text { male } \\
\text { juvenile } \\
\text { holotype }\end{array}$ & $\begin{array}{c}\text { male } \\
\text { juvenile } \\
\text { holotype }\end{array}$ & $\begin{array}{c}\text { male } \\
\text { juvenile } \\
\text { paratype }\end{array}$ \\
\hline Tail at D1 origin (height) & 0.8 & 0.8 & 0.8 & 0.7 & 0.7 & 0.8 & 0.6 \\
\hline D1 base length & 3.2 & 3.8 & 3.3 & 3.8 & 3.5 & 3.0 & 2.6 \\
\hline D1 height & 1.7 & 1.2 & 1.2 & 1.4 & 1.5 & 1.3 & 1.3 \\
\hline D1 origin to caudal-fin tip & 10.7 & 13.2 & 13.6 & 14.8 & 10.5 & 13.0 & 14.9 \\
\hline D2 origin to caudal-fin tip & 7.3 & 9.0 & 10.8 & 10.7 & 7.3 & 9.2 & 9.4 \\
\hline Caudal-fin length & 4.1 & 4.8 & 5.6 & 6.3 & 3.7 & 4.9 & 4.9 \\
\hline Interdorsal & 0.3 & 0.7 & 0.8 & 0.8 & 0.7 & 1.0 & 2.0 \\
\hline
\end{tabular}

epichordal lobe of caudal fin; however, fold width less than tail width. Dorsal fins of similar shape and size; rather short and moderately tall with evenly convex anterior margin, straight or slightly convex posterior margin and a pointed tip; separated by an interspace, $52 \%$ length of first dorsal-fin base. Epichordal caudal-fin lobe low, separated by short interspace from and distinctly longer than second dorsal-fin base; hypochordal caudal lobe very small, low, originating near end of lateral fold, confluent with epichordal lobe.

Dorsal surface of disc densely and finely prickled, denticles bristle-like; denticles erect with very slightly curved crowns, on radiate base embedded in skin. A single small, but conspicuous preorbital thorn. Tail prickled dorsally; an irregular mediodorsal row of about 45 small thorns extending from level of pelvic axil to first dorsal-fin origin; thorns with oval, radiate root and a compressed, hooked crown. Ventral surface of disc and pelvic fins totally naked. Ventral surface of tail fined prickled, its base naked. No malar or alar thorns in this juvenile male holotype.

Tooth rows in upper jaw 41; lower jaw 38. Pectoral propterygial radials 32; mesopterygial radials 16 ; metapterygial radials 26; total radials 74 . Monospondylous centra 27; diplospondylous predorsal centra 81; predorsal centra 108; caudal centra 35; total diplospondylous centra 116; total centra 143.

\section{Colour (in preservative)}

Dorsal surface pale greyish brown; eyes, dorsal-fin and caudal-fin margins, and lateral tail folds darker. Ventral surface whitish, with small pale brownish blotches scattered mainly on outer disc margins and on anterior pelvic lobes; cloaca whitish surrounded by faded brownish markings.

\section{Size}

Known only from the juvenile male holotype of $440 \mathrm{~mm}$ TL.

\section{REMARKS}

Although described from a single juvenile male, this species has distinctive morphological and meristic features that set it clearly apart from its congeners and all other skates of the region. Its general appearance resembles some species of Bathyraja and Indo-Australian legskates (family Anacanthobatidae von Bonde \& Swart, 1924) in having a thin, flabby disc, and long, projecting snout with a narrow, twisted rostral cartilage that is visible both dorsally and ventrally. However, its tail shape is more typical of skates than legskates (thicker, with well-developed dorsal fins, lateral tail folds and denticles). Like other species of Notoraja, it has a rostral cartilage continuous with chondrocranium, stout proximally but very slender and uncalcified distally (Fig. 12), broadly oval nasal capsules with 
basal fenestrae (vs narrow capsules without basal fenestrae in Bathyraja) and a narrow internasal plate in the chondrocranium (broad in Bathyraja, see McEachran \& Miyake 1990), the precerebral fontanelle is narrow and extends anterior to leading edge of the nasal capsules (vs broad precerebral fontanelle not extending anterior to nasal capsules in Bathyraja, see McEachan \& Dunn 1998), and lower abdominal vertebral counts (27 vs $28-48$, rarely fewer than 30 in Bathyraja; Stehmann 2005). Based on meristic data for 21 species of Bathyraja (Stehmann, 2005), only B. richardsoni (Garrick, 1961) has an equally high tooth row count in the upper jaw (41 in $N$. inusitata $n$. sp. and 44 in $B$. richardsoni vs $18-36$ in the other 20 species). Notoraja inusitata n. sp. can be distinguished from other Notoraja species of the region by the features discussed above, its small but distinctly triangular snout tip, naked ventral disc, configuration of the medio-dorsal thorns on the tail, broader lateral tail folds originating at the level of the posterior lobe of the pelvic fin, and more pectoral-fin radials (74 vs 62-66) than its congeners.

The genus Insentiraja was initially defined as a subgenus of Pavoraja Whitley, 1939 by Yearsley \& Last (1992) for their new species P. laxipella. It is defined by the absence of thorns on tail and mid-dorsal region of trunk, and presently includes I. laxipella and I. subtilispinosa (Stehmann, 1989). Our new species bears some resemblance to Insentiraja skates (e.g., soft body with loose skin, ventral skin almost transparent) but differs in having a distinct mid-dorsal row of thorns on its tail. Our specimen is a juvenile male and this row might atrophy with growth, but other characters distinguish it from Insentiraja skates: e.g., less dense covering of dermal denticles on the dorsal surface of the disc and ventral surface of the tail, greater numbers of precaudal vertebrae (116 vs 95-95) and pectoral radials (74 vs 64-66); see Yearsley \& Last 1992 and Ishihara \& Stehmann 1990.

Notoraja fijiensis n. sp.

(Figs 13-15; Tables 2, 3)

HolotyPe. - MNHN 1999-0450, female 386 mm TL, cruise MUSORSTOM 10, R/V Alis, Fiji, stn CP1312, $17^{\circ} 24.52^{\prime} S, 178^{\circ} 34.00^{\prime} \mathrm{E}, 660 / 666 \mathrm{~m}$ depth, beam trawl, 5.VIII.1998.

PARATYPES. - 3 specimens. MNHN 1999-0452, immature male $307 \mathrm{~mm}$ TL, cruise MUSORSTOM 10, R/V Alis, Fiji, stn CP1337, 17³.44'S, 17847.21’E, 635/670 m depth, beam trawl, 9.VIII.1998. - MNHN 1999-0453, female juvenile $217 \mathrm{~mm}$ TL, cruise MUSORSTOM 10, R/V Alis, Fiji, stn CP1337, 17³.44'S, 17847.21'E, 635/670 m depth, beam trawl, 9.VIII.1998. - MNHN 1999-0451, immature male $212 \mathrm{~mm}$ TL, cruise MUSORSTOM 10, R/V Alis, Fiji, stn CP1330, 17 $9.50^{\circ} \mathrm{S}$, $178^{\circ} 56.32^{\prime} \mathrm{E}, 567 / 699 \mathrm{~m}$ depth, beam trawl, 8.VIII.1998.

Distribution. - Known from the slope of the Fiji Islands, between 567 and $699 \mathrm{~m}$ depth (Fig. 18).

Eтymology. - Based on the Fiji Islands where the type specimens were collected.

DiAGNOSIS. - A species of Notoraja (probably of medium size) with the following combination of characters: a small but conspicuous preorbital thorn; dorsal surface of disc entirely velvety, covered with fine denticles; ventral surface velvety with widely spaced and very fine denticles; tail long and slender, entirely velvety, without enlarged thorns; lateral tail folds not expanded distally, narrower than tail for their whole length; nasal lobes not greatly expanded, width of nasal curtain 7.3-8.3\% TL; mouth relatively small, its width more than $66 \%$ of maximum width of nasal curtain and 5.7-6.2\% TL; anterior pelvic-fin lobe shorter that posterior lobe; dorsal surfaces plain pale yellowish brown, ventral surface creamy white; total pectoral-fin radials 64-66, monospondylous centra 25, total diplospondylous centra 119-127, total number of centra 144-152.

\section{DESCRIPTION}

Disc heart-shaped, 1.18 times as broad as long in holotype (1.11-1.16 in paratypes); maximum angle in front of spiracles $98^{\circ}\left(91-98^{\circ}\right)$; anterior margin weakly undulate, slightly concave on either side of tip of snout, convex from anterior extension of propterygium to anterior margin of orbit, concave to level of spiracle; outer corner broadly rounded; posterolateral margin moderately convex. Axis of greatest width 56\% (53-60\%) of disc length. Preorbital snout length 2.56 (2.48-3.26) times orbit length, 3.55 (3.35-3.90) times interorbital width; preoral snout length 1.86 (1.97-2.13) times internarial distance. Orbit diameter 1.39 (1.20-1.35) times interorbital distance, 2.02 (1.96-3.11) times length of spiracles. Nasal lobes not greatly expanded and 


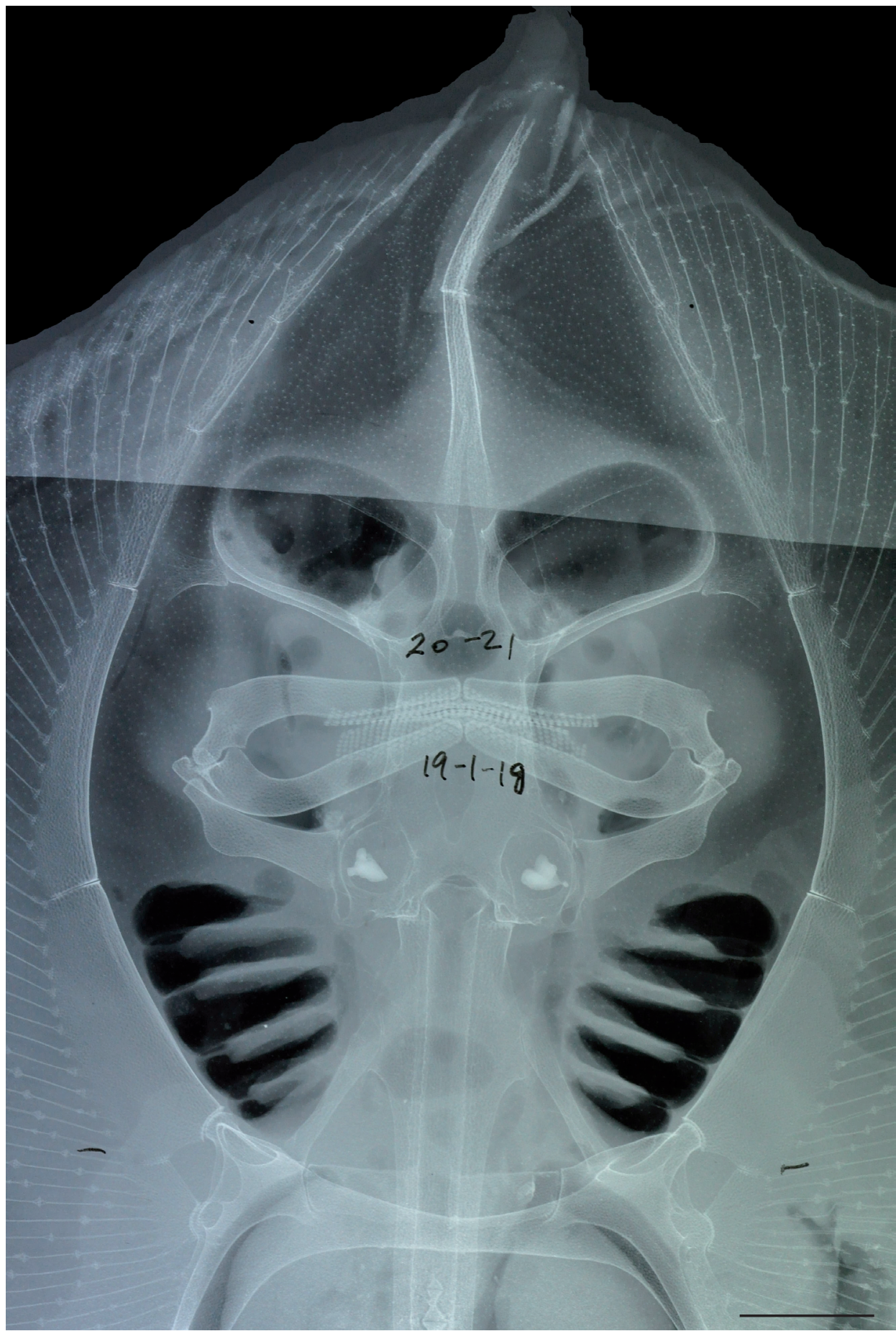

FIG. 12. - Radiograph of the head of Notoraja inusitata n. sp., holotype (MNHN 2008-1638, male juvenile $444 \mathrm{~mm}$ TL). Scale bar: $1 \mathrm{~cm}$. 


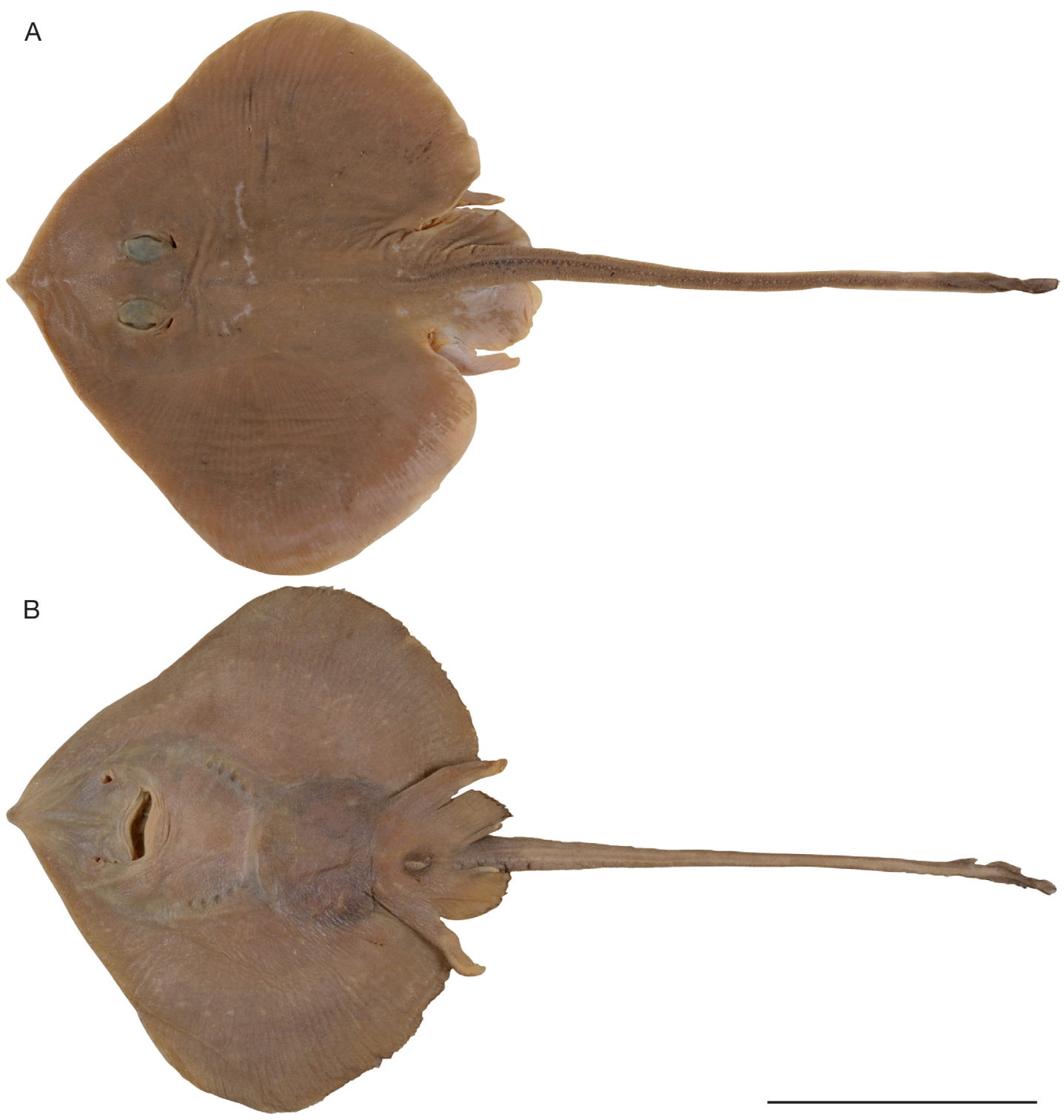

FIG. 13. - Notoraja fijiensis n. sp., holotype (MNHN 1999-0450, female $386 \mathrm{~mm} \mathrm{TL):} \mathrm{A,} \mathrm{dorsal} \mathrm{surface;} \mathrm{B,} \mathrm{ventral} \mathrm{surface.} \mathrm{Scale}$ bar: $10 \mathrm{~cm}$.

rounded; posterior margin shortly and flabby fringed. Mouth small, its width more than $66 \%$ of maximum width of nasal curtain. Upper and lower jaws weakly arched. Teeth plate-like, with short cusps; arranged in quincunx in female holotype and juveniles paratypes. Distance between first gill slits
1.86 (1.63-1.70) times longer than distance between nostrils; distance between fifth gill slits 1.23 (0.911.10) times longer than distance between nostrils. Pelvic fins deeply incised with lobes connected by radials and membranes; anterior lobe moderately long, slightly shorter than posterior lobe in holotype 


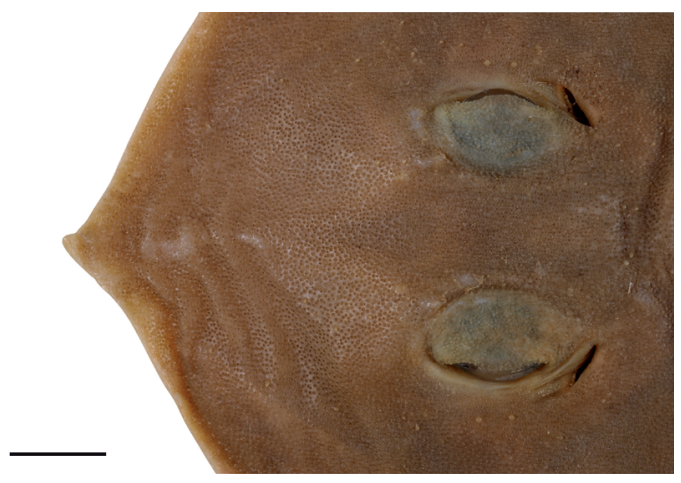

FIG. 14. - Dorsal head of Notoraja fijiensis n. sp., holotype (MNHN 1999-0450, female $386 \mathrm{~mm}$ TL). Scale bar: $1 \mathrm{~cm}$.

(longer than posterior lobe in paratypes), finger-like, tapering to blunt point distally; posterior lobe with convex lateral margins. Tail narrow at base, oval, depressed slightly, tapering gradually posteriorly; very convex dorsally, weakly convex ventrally; tail width at axil of pelvic fin 2.43 (2.00) times width at midlength of tail, and 2.51 (2.53-2.77) times width at dorsal-fin origin respectively; length from rear of cloaca 1.28 (1.37-1.43) times distance from tip of snout to rear of cloaca; width 1.52 (1.361.51) times height at axil of pelvic fin; width at first dorsal-fin origin 2.03 times height (1.39-1.44); lateral skin folds originating near anterior third of tail, extending to distal third of epichordal caudalfin lobe and broadening distally; fold width always less than tail width. Dorsal fins of similar shape and size; moderately tall, flag-like with evenly convex anterior margin, slightly convex posterior margin and a pointed tip; separated by very short interspace, $10.4 \%$ (4.0-5.0\%) length of first dorsal-fin base. Epichordal caudal-fin lobe well developed, separated by short interspace from the second dorsal fin, slightly longer than second dorsal-fin base; hypochordal caudal lobe very low, originating near end of lateral fold, confluent with epichordal lobe.

Dorsal surface entirely covered with fine, bristlelike dermal denticles, with conical bases; denticles partly embedded in skin; crown exposed, erect, slightly curved. Ventral surface less well covered with tiny, very widely spaced denticles (smallest paratypes almost naked), their shape similar to

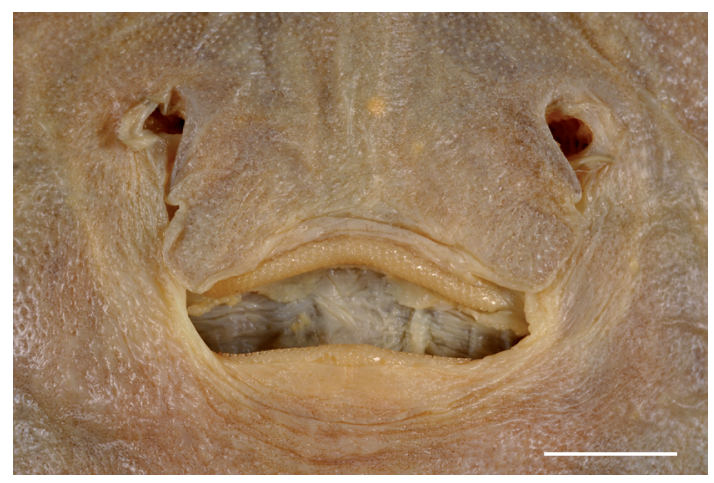

FIG. 15. - Oronasal region of Notoraja fijiensis n. sp., holotype (MNHN 1999-0450, female 386 mm TL). Scale bar: $1 \mathrm{~cm}$.

those of dorsal surface; belly and pelvic fins mostly devoid of denticles. A conspicuous preorbital thorn. Dorsal and ventral surfaces of tail velvety; dorsal mid line without obvious thorn, instead with an irregular row of slightly enlarged denticles. Malar and alar thorns not developed in female and juvenile male types.

Tooth rows in upper jaw 32 in holotype (37-38 in paratypes); lower jaw 35 (38-40). Pectoral propterygial radials 29-30 (29); mesopterygial radials 11-12 (11-12); metapterygial radials 23 (23-25); total radials 64 (64-66). Monospondylous centra 25 (25); diplospondylous predorsal centra 80 (77-81); predorsal centra 105 (102-106); caudal centra 41 (38-44); total diplospondylous centra 121 (119127); total centra 146 (144-152).

\section{Colour (in preservative)}

Dorsal surface plain pale yellowish brown, outer disc margin paler; eyes greyish; midline of tail dusky; dorsal and caudal fins dusky with darker edges; ventral surface of disc and tail creamy white.

\section{Size}

Reaches at least $395 \mathrm{~mm}$ TL based on the female holotype; a male of $310 \mathrm{~mm}$ TL was still immature.

\section{REMARKS}

Notoraja fijiensis n. sp. is distinguishable from $N$. alisae n. sp. by its much paler colouration, being pale yellowish brown dorsally (rather than 


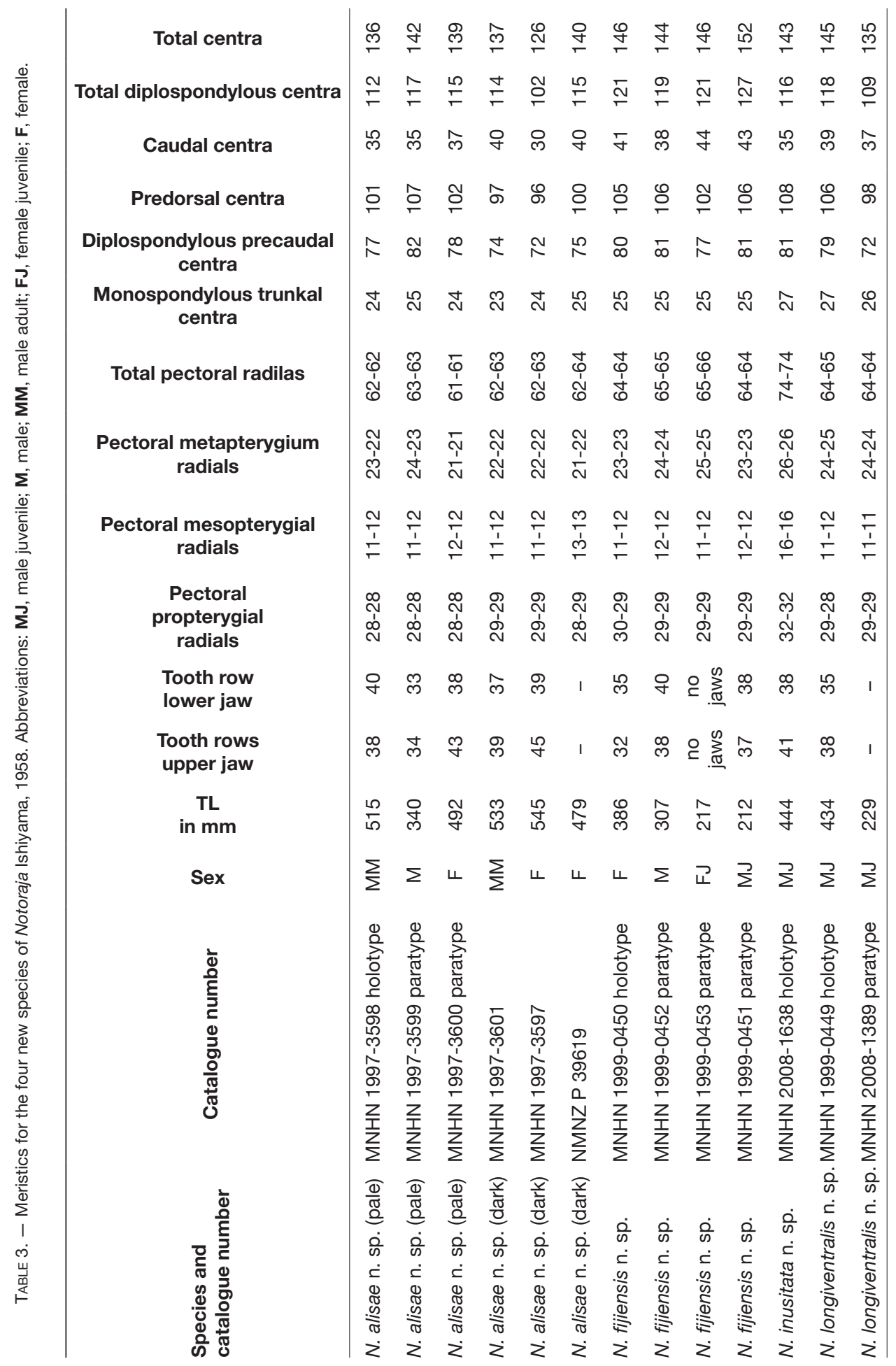


pale greyish brown) and whitish ventrally (rather than dusky yellow), shorter denticles on the dorsal disc, relatively broader predorsal tail, and having larger much darker dorsal fins. Also, it has a more obvious heart-shaped disc with a weakly undulate anterior margin, and its preorbital thorns are more conspicuous.

\section{Notoraja longiventralis $\mathrm{n} . \mathrm{sp}$.}

(Figs 16-18; Tables 2, 3)

Notoraja sp. 1 - Séret in Fricke et al. (2011): listed p. 5.

Holotype. - MNHN 1999-0449, male juvenile $434 \mathrm{~mm}$ TL, Fiji, cruise MUSORSTOM 10, R/V Alis, Fiji, stn CP1361, $18^{\circ} 0^{\prime} \mathrm{S}, 178^{\circ} 53^{\prime} \mathrm{E}, 660 / 666 \mathrm{~m}$ depth, 5.VIII.1998, beam trawl.

PARATYPES. - 2 specimens. MNHN 2008-1389 (field number DHS 402, tissue sample ICTI-001495), male juvenile 229 mm TL, MNHN 2008-1388 (field number DHS 401, tissue sample ICTI-001496), newborn male $168 \mathrm{~mm}$ TL, SANTO expedition, R/V Alis, Vanuatu, NE Tubula Island, stn AT60, $15^{\circ} 33^{\prime} \mathrm{S}, 167^{\circ} 22^{\prime} \mathrm{E}, 880 / 953 \mathrm{~m}$ depth, 3.X.2006, beam trawl.

Distribution. - On the insular slopes off the Fiji Islands, and off Tubula Island (Vanuatu), between 660 and $953 \mathrm{~m}$ depth (Fig. 18).

Etymology. - From the Latin "longi", long, and "ventralis", in reference to the very long anterior lobe of the pelvic fin.

DiagNOSIS. - A species of Notoraja (probably of medium size) with the following combination of characters: single rudimentary preorbital thorn; dorsal and ventral surfaces of disc entirely velvety, covered with fine denticles; tail long and slender, entirely velvety, without enlarged thorns; lateral tail folds not expanded distally, always narrower than tail width; nasal lobes not greatly expanded, width of nasal curtain 7.6-8.0\% TL; mouth relatively broad, its width more than $66 \%$ of maximum width of nasal curtain; anterior pelvic-fin lobe longer that posterior lobe; dorsal and ventral surfaces dark, almost uniformly purplish grey; faint whitish spots over pores along the anterior margins of disc; total pectoral-fin radials 64-65, monospondylous centra 26-27, total diplospondylous centra 109-118, total number of centra 135-145.

\section{DESCRIPTION}

Disc heart-shaped, 1.13 (1.13) times as broad as long; maximum angle in front of spiracles $92^{\circ}$ $\left(108^{\circ}\right)$; anterior margin very weakly undulate: slightly concave on either side of tip of snout, convex from anterior extension of propterygium to anterior margin of orbit, concave to level of spiracle; outer corner broadly rounded; posterolateral margin moderately convex. Axis of greatest width $58 \%(61 \%)$ of disc length. Preorbital snout length 3.29 (2.62) times orbit length, 3.65 (3.01) times interorbital width; preoral snout length 1.81 (1.94) times internarial distance. Orbit diameter 1.11 (1.15) times interorbital distance, and 1.53 (2.42) times length of spiracles. Nasal lobes not greatly expanded and rounded, posterior margin shortly and flabby, weakly fringed. Mouth wide, width more than $66 \%$ of maximum width of nasal curtain. Upper and lower jaws weakly arched. Teeth plate-like, with short cusps arranged in quincunx in juvenile male holotype. Distance between first gill slits 1.60 (1.67) times larger than between nostrils; distance between fifth gill slits 1.07 (1.03) times larger than between nostrils.

Pelvic fins deeply incised with lobes connected by radials and membranes; anterior lobe much longer than posterior lobe, finger-like, tapering with pointed tip; posterior lobe with convex lateral margins, posterior margin crenate due to extension of posterior radials. Tail narrow at base, depressed oval over length; strongly convex dorsally, weakly convex ventrally; tapering gradually posteriorly, becoming very slender toward tip; tail width at axils of pelvic fins 2.49 (2.20) times width at midlength of tail, and 3.00 (4.10) times width at dorsal-fin origin respectively; length from rear of cloaca 1.54 (1.58) times distance from tip of snout to rear of cloaca; width 1.48 (1.61) times height at axil of pelvic fin, and width at first dorsal-fin origin 1.29 times height (1.17); lateral skin folds near anterior third of tail, extending to proximal half of epichordal caudal-fin lobe and slightly broadening distally, its width always much less than tail width. Dorsal fins of similar shape and size; flag-like, moderately tall with an evenly convex anterior margin, slightly convex posterior margin and a pointed tip; interdorsal space short, 29\% (13\%) length of first dorsal-fin base. Epichordal caudal-fin lobe relatively well developed, separated by short interspace from and distinctly shorter than second dorsal-fin base; 


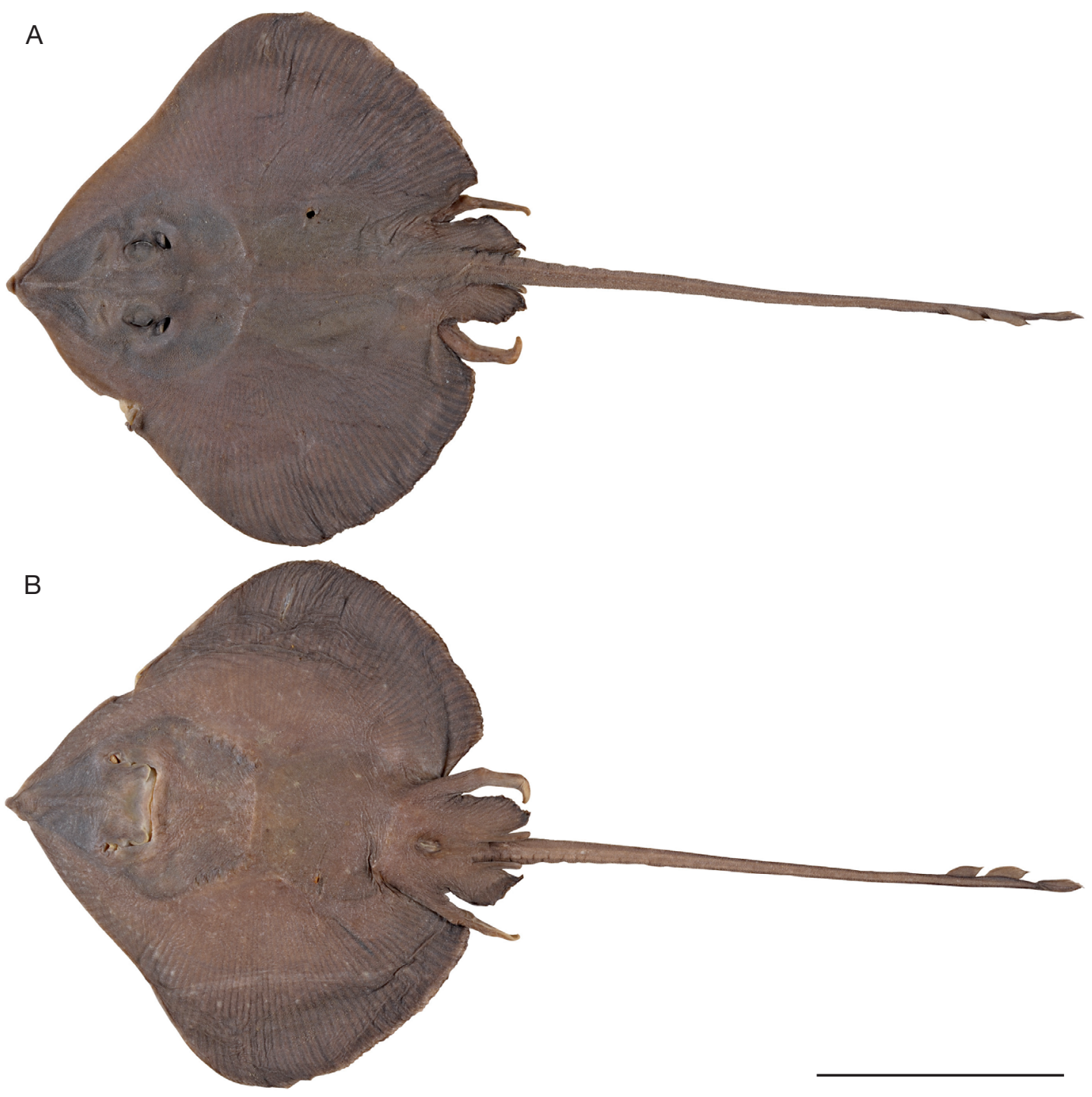

FIG. 16. - Notoraja longiventralis n. sp., holotype (MNHN 1999-0449, male juvenile 434 mm TL): A, dorsal surface; B, ventral surface. Scale bar: $10 \mathrm{~cm}$.

hypochordal caudal lobe developed, its height about half of that of epichordal lobe, originating near end of lateral fold, confluent with epichordal lobe. Male holotype entirely covered with fine dermal denticles on both dorsal and ventral surfaces; denticles densely spaced, bristle-like, with an erect, pointed crown. Single rudimentary preorbital thorn (even in juveniles). Tail uniformly velvety; median thorns rudimentary (barely detectable in juvenile male holotype and greatly reduced in smaller juvenile paratypes). Malar and alar thorns not developed in holotype.

Tooth rows in upper jaw 38 of holotype; 35 in lower jaw. Pectoral propterygial radials 28-29 in holotype (29 in paratype); mesopterygial radials 11-12 (12); metapterygial radials 25 (24); total radials 64-65 (64). 


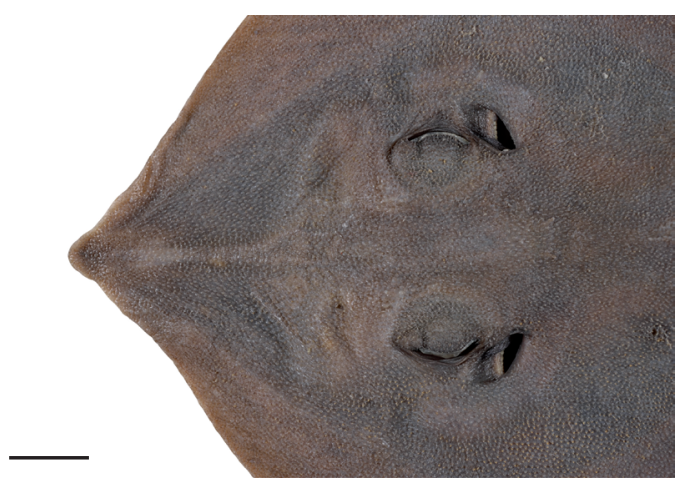

FIG. 17. - Dorsal head of Notoraja longiventralis n. sp., holotype (MNHN 1999-0449, male juvenile $434 \mathrm{~mm}$ TL). Scale bar: $1 \mathrm{~cm}$.

Monospondylous centra 27 (26); diplospondylous predorsal centra 79 (72); predorsal centra 106 (98); caudal centra 39 (37); total diplospondylous centra 118 (109); total centra 145 (135).

\section{Colour (in preservative)}

Dorsal and ventral surfaces dark purplish grey, faint whitish spots scattered on ventral surface, mainly at level of pores along the anterior margins of disc.

\section{Size}

Reaches at least $434 \mathrm{~mm}$ TL from holotype juvenile male; newborn at $168 \mathrm{~mm}$ TL.

\section{REMARKS}

Notoraja longiventralis $\mathrm{n}$. sp. is set apart from the other velcro skates described above by its much darker dorsal and ventral colouration, its unusually long and pointed anterior pelvic-fin lobes which extend beyond the tip of the posterior lobe, and generally longer interdorsal distance and shorter dorsal head length.

\section{DISCUSSION}

Two other Notoraja species have been described from nearby parts of the southwest Pacific: $N$. ochroderma from the Coral Sea and N. sapphira from the Norfolk Ridge. The pale skate $N$. ochroderma, known from the continental slope off northeastern Australia

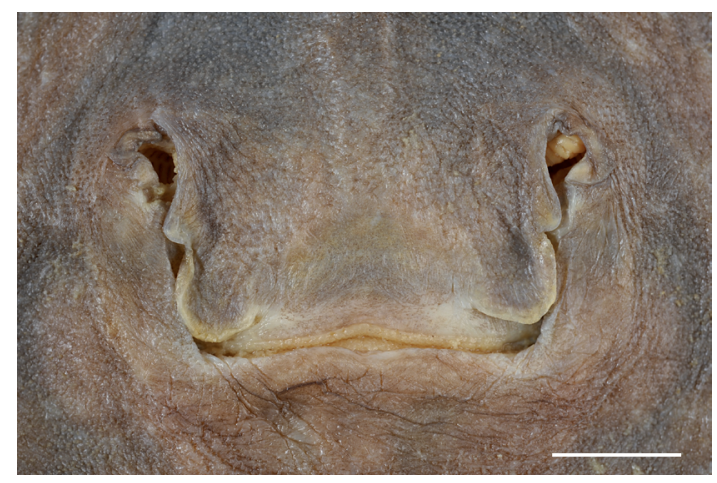

FIG. 18. - Oronasal region of Notoraja longiventralis n. sp., holotype (MNHN 1999-0449, male juvenile 434 mm TL). Scale bar: $1 \mathrm{~cm}$.

(near Cairns), is distinguishable by plain pale yellow or white dorsal and ventral surfaces, absence of a preorbital thorn, 1-3 rows of thorns on tail, an indistinct lateral tail fold, a smooth ventral surface of the disc, a very bulbous clasper, and a dark band through the second dorsal fin. The sapphire skate, N. sapphira, known from the Norfolk Ridge, is distinguishable by its strikingly rich blue dorsal colouration, a dorsal surface largely free of dermal denticles, a totally smooth and blackish ventral surface, and a densely prickled tail.

Other new velcro skates (under description by Last $e t$ al.) occur around the main islands of $\mathrm{New}$ Zealand, as well as on the Chatham Rise, east of New Zealand. These species, which appear to attain a larger size (to $67-89 \mathrm{~cm}$ TL as adults), differ in morphometrics including having a wider disc, and like $N$. longiventralis n. sp. are dark coloured on both surfaces. It is also likely that additional velcro skates remain undiscovered in the unexplored depths of the Indo-Pacific region.

Although conservative in many characters, skates of the genus Notoraja seem to be intra- and interspecifically variable in colouration and dermal armature, and their distributions tend to show that they are either locally restricted or, conversely, have a broad geographic range. Given the variability of key characters defining the genus (i.e. head, denticle and clasper morphologies), the group may not be monophyletic based on its present definition. Hence, relationships between Australian, New Caledonian 


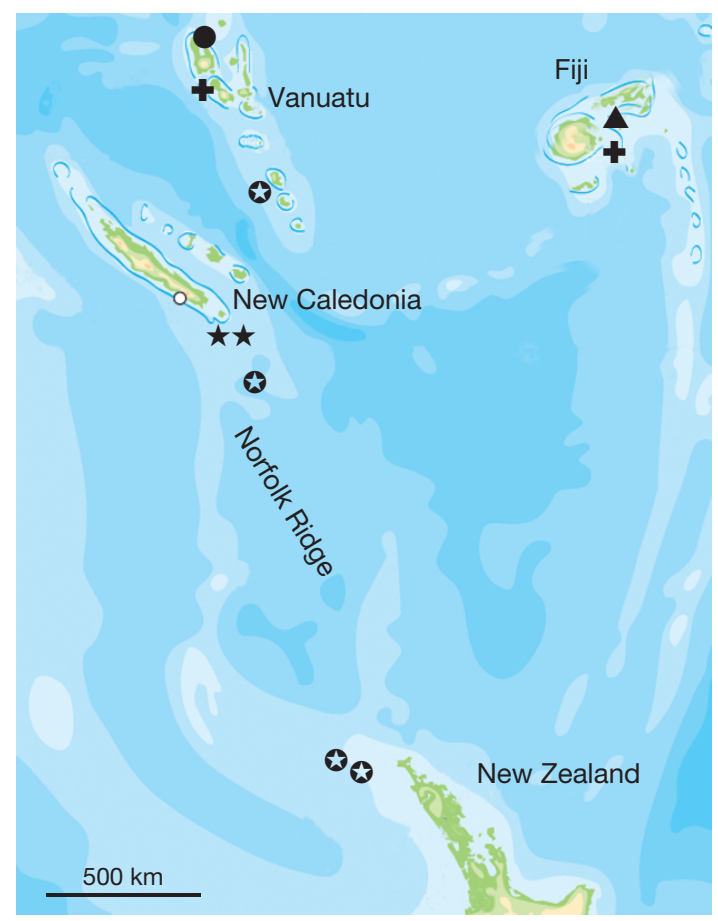

FIG. 19. - Map of the southwestern Pacific Ocean showing the capture localities of the four species of Notoraja Ishiyama, 1958: $\star$, N. alisae n. sp. ( $\boldsymbol{\bullet}$,dark morph); $\boldsymbol{\bullet}, N$. inusitata n. sp.; $\boldsymbol{\Delta}, N$. fijiensis n. sp.; +, N. longiventralis $\mathrm{n}$. sp.

and New Zealand species, and the type species of the genus, the Japanese $N$. tobitukai, need further investigation.

\section{Acknowledgements}

The SANTO 2006 expedition was organised by $\mathrm{Mu}$ séum national d'Histoire naturelle, Paris, Pro-Natura International (PNI), and Institut de Recherche pour le Développement (IRD). It operated under a permit granted to Philippe Bouchet (MNHN) by the Environment Unit of the Government of Vanuatu. The Marine Biodiversity part of the expedition, a part of Census of Marine Life's CReefs programme, was specifically funded by grants from the Total Foundation and the Sloan Foundation. We thank the team of the Australian National Fish collection in Hobart, particularly Alastair Graham for curation of specimens, John Pogonoski for taking radiographs and the meristic counts, and Louise Conboy for photographs and etching of images for figures. We also thank IRD colleagues René Grandperrin, Bertrand Richer de Forges and Sarah Samadi, and Philippe Bouchet (MNHN, Paris), who led French exploratory cruises off New Caledonia, Vanuatu and Fiji, our NMNZ (Te Papa Museum) colleague, Clive Roberts, who was an initiator and co-leader of the NORFANZ survey, and the referees J. McEachran, H. Ishihara and A. Ohler for their useful comments.

\section{REFERENCES}

Compagno L. J. V., Last P. R., Stevens J. D. \& Alava M. N. R. 2005. - Checklist of Philippine Chondrichthyes. Commonwealth Scientific and Industrial Research Organisation (CSIRO) Marine Laboratories Report 243, 103 p.

Fricke R., Earle J. L., Pyle R. L. \& Séret B. 2011. Checklist of the fishes, in BOUCHET P., LE GUYADER H. \& PASCAL O. (eds), The Natural History of Santo. Patrimoines Naturels 70. Muséum national d'Histoire naturelle, Paris; IRD, Marseille; Pro-Natura International, Paris: 383-409.

GARrick J. A. F. \& PAUL L. J. 1974. — The taxonomy of New Zealand skates (suborder Rajoidea), with description of three new species. Journal of the Royal Society New Zealand 4: 345-377.

Grandperrin R., Bujan S., Menou J.-L., Richer De Forges B. \& Rivaton J. 1995. - Campagne HALIPRO 1 de chalutages exploratoires dans l'est et dans le sud de la Nouvelle-Calédonie (N.O. Alis 18-25 mars et 29 mars-1er avril 1994). Conventions-Sciences de la mer-Biologie marine. NouméaORSTOM 14, $61 \mathrm{p}$.

GrandPERrin R., FARMAN R., LORANCE P., JOMESSY T., Hamel P., Laboute P., Labrosse P., RiCher DE Forges B., SÉret B. \& Virly S. 1997. - Campagne HALIPRO 2 de chalutages profonds dans le sud de la zone économique de Nouvelle-Calédonie ( $R / V$ Tangaroa, 4-28 novembre 1996). ZoNéCo, 150 p.

ISHIHARA H. \& STEHMANN M. 1990. - A second record of the deep-water skate Notoraja subtilispinosa from the Flores Sea, Indonesia. Japanese Journal of Zoology 37 (2): 182-186.

LAST P. R. \& MCEACHRAN J. D. 2006. — New softnose skate genus Brochiraja from New Zealand (Rajidae: Arhynchobatinae) with description of four new species. New Zealand Journal of Marine and Freshwater Research 40: 65-90.

Last P. R., White W. T., Pogonoski J. J. \& Gledhill D. C. (eds) 2008. — New Australian skates - background 
and methodology, in Descriptions of new Australian skates (Batoidea: Rajoidei). Commonwealth Scientific and Industrial Research Organisation (CSIRO) Research Paper 021: 1-8.

Leviton A. E., Gibbs R. H. JR, Heal E. \& Dawson C. E. 1985. - Standards in herpetology and ichthyology: Part I. Standard symbolic codes for institutional resource collections in herpetology and ichthyology. Copeia 1985: 802-832.

McEachran J. D. \& Miyake T. 1990. — Phylogenetic interrelationships of skates: a working hypothesis (Chondrichthyes, Rajoidei), in PrATT JR H. L., Gruber S. H. \& TANiUCHI T. (eds), Elasmobranchs as living resources: advances in the biology, ecology, systematics, and the status of the fisheries. NOAA Technical Report 90: 285-304.

McEACHRAn J. D. \& LAST P. R. 1994. - New species of skate, Notoraja ochroderma, from off Queensland, Australia, with comments on the taxonomic limits of Notoraja (Chondrichthyes, Rajoidei). Copeia 1994: 413-421.

McEachran J. D. \& Dunn K. A. 1998. - Phylogenetic analysis of skates, a morphologically conservative clade of Elasmobranchs (Chondrichthyes: Rajidae). Copeia 1998: 271-290.

McEACHRAN J. D. \& LAST P. R. 2008. - New deepwater skates of the genus Notoraja (Rajoidei: Arhynchobatidae) from southern Australia and the eastern Indian Ocean, in Last P. R., White W. T., Pogonoski J. J. \& Gledhill D. C. (eds), Descriptions of new Australian skates (Batoidea: Rajoidei). Commonwealth Scientific and Industrial Research Organisation (CSIRO) Research Paper 021: 155-172.

Richer de Forges B., Faliex E. \& Menou J-L. 1996. La campagne MUSORSTOM 8 dans l'archipel de Va- nuatu. Compte-rendu et liste des stations, in CROSNIER A. (ed.), Résultats des campagnes MUSORSTOM. Volume 15. Mémoires du Muséum national d'Histoire naturelle 168: 9-32.

SÉRET B. 1997. - Poissons de profondeur de NouvelleCalédonie: apports des campagnes MUSORSTOM. Deepwater fishes of New-Caledonia: contributions of the MUSORSTOM cruises, in SÉRET B. (ed.), Résultats des campagnes MUSORSTOM. Volume 17. Mémoires du Muséum national d'Histoire naturelle 174: 9-16.

Séret B. \& LaST P. R. 2009. - Notoraja sapphira n. sp. (Rajoidei: Arhynchobatidae), a new deepwater skate from the slopes of the Norfolk Ridge (south-west Pacfic). Zootaxa 2153: 24-34.

STEHMANN M. F. W. 1989. — Resurrection of Notoraja Ishiyama, 1958 and description of a new species of deep-water skate from the South China Sea Notoraja subtilispinosa n. sp. (Pisces, Batoidea, Rajidae). Mémoires du Muséum national d'Histoire naturelle, nouvelle série, série A. Zool. 143: 247-260.

STEHMANN M. F. W. 2005. - Bathyraja ishiharai n. sp., a new deep-water skate from the eastern Indian Ocean on the Naturalist Plateau off southwestern Australia (Elasmobranchii, Rajiformes, Rajidae). Journal of Ichthyology 45: S39-57.

Williams A., Gowlett-Holmes K. \& Althaus F. (eds) 2006. - Explore lost world of the deep. NORFANZ Voyage. 10 May to 8 June 2003. Final report to the Department of the Environment and Heritage ( $\mathrm{Na}$ tional Oceans Office). June 2006. Biodiversity survey of seamounts \& slopes of the Norfolk Ridge and Lord Howe Rise. NIWA \& CSIRO, 591 p.

YeARSLEy G. K. \& LAST P. R. 1992. - Pavoraja (Insentiraja) laxipella, a new subgenus and species of skate (Chondrichthyes: Rajoidei). Copeia 1992: 839-850. 